\title{
Content
}

Foreward and Executive Summary …........................................................................ 7

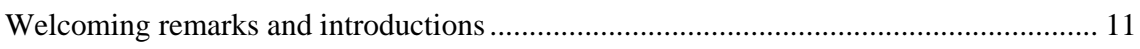

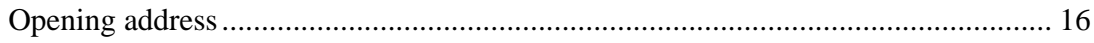

Part 1. Changes in Climate, Fish Stocks and Aquaculture................................................ 19

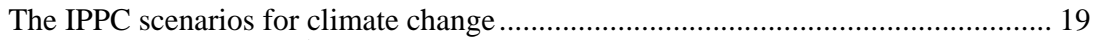

Modelling of $20^{\text {th }}$ century climate. Robust findings: ........................................... 19

Modelling of future climate. Robust findings: .............................................. 19

Modelling of future climate. Key uncertainties:........................................... 20

Ocean climate variations and predictions in the Northeast Atlantic Ocean ................. 21

Part 1. Changes in Climate, Fish Stocks and Aquaculture............................................... 23

Predictions of changing fish stock production, distribution and migrations in the Northeast Atlantic ................................................................................ 23

Impact of $21^{\text {st }}$ century climate change on the Baltic Sea fish community and fisheries ............................................................................................... 24

Climate change impacts on the marine ecosystems of the North Sea and west of the British Isles .................................................................................... 26

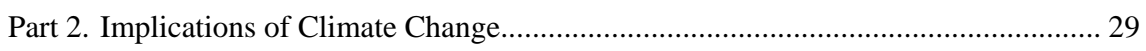

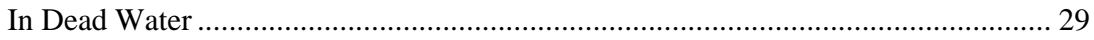

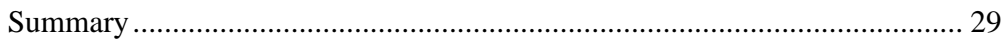

Climate Change and Fisheries in the North Sea and West of Scotland ...................... 34

Will the Polar waters become the new fishing grounds? ............................................. 36

Tackling climate change impacts on fisheries .......................................................... 38

Reducing fishing mortality is a win-win strategy for overfishing and adaptation to climate change. ......................................................... 39

Aquatic organisms and diseases - an underlying threat when cold seas heat? ............ 41

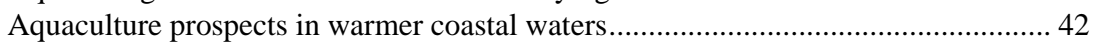

Aquatic organisms and diseases - an underlying threat when cold seas heat? ............ 44

Part 2. Implications of Climate Change........................................................................ 47

An economic perspective on management implications of climate change................ 47

Socioeconomic consequences of climate change in fisheries: a progress

report of ongoing research. ..................................................................... 49

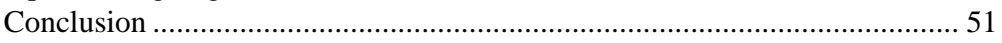

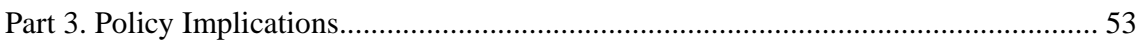

Policy and management implications in fisheries of climate change.......................... 53

Policy implications and the fisheries management toolbox............................. 53

Policy implications of climate change and fisheries...................................... 54

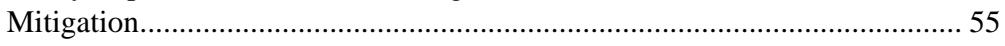

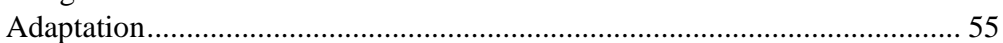

EU fisheries, climate change and management implications.................................... 56

Challenges for the fishing industry.......................................................................... 59

Climate change from an indigenous people perspective............................................. 60

Climate change effects on aquaculture and adaptation measures for a growing

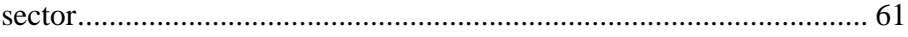

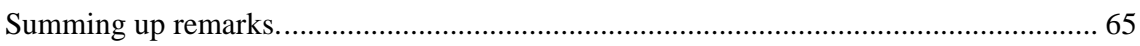

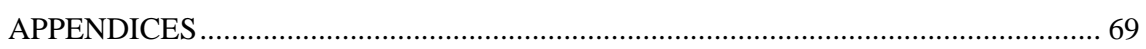

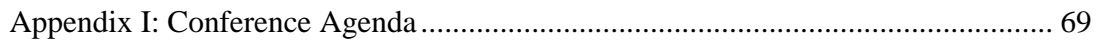

Appendix II: List of participants ............................................................................ 72 



\section{Foreward and Executive Summary}

\section{Background}

In order to help prepare fisheries management authorities and regional fisheries management organizations charged with the Northeast Atlantic Ocean and the Baltic Sea for the implications of climate change, the Norwegian Ministry of Fisheries and Coastal Affairs, the EU Commission, Directorate General for Fisheries and Maritime Affairs, and the Nordic Council of Ministers commissioned a Conference that was convened in Bergen, Norway, 17-18 April 2008.

The themes covered at the Conference were climate change related

- physical and biological changes of the Northeast Atlantic Ocean, the North Sea and the Baltic Sea;

- implications for fisheries and aquaculture (e.g. the productivity and distribution of fish stocks, changes in productivity and disease patterns in aquaculture, fishing fleet structure, fishing methods, fish processing and transportation, aquaculture species and facility location, feed supply);

- policy and management implications for governments, the European Commission and the regional fisheries management organizations such as NEAFC and the Joint Norwegian Russian Fisheries Commission (e.g. fisheries contribution to mitigation, new reference points and ecosystem considerations, changes towards adaptive management regimes, assistance to industry adaptation, implications for partitioning of access to resources) .

Expert presentations to the Conference were by invitation.

\section{Summary of the expert presentations}

\section{Changes in ocean climate.}

The oceans are generally predicted to experience less warming than continents, and this is especially true for the North Atlantic. In this region, the observed long-term natural variability in ocean temperature since 1900 has an amplitude of about $0.7{ }^{\circ} \mathrm{C}$. The predicted temperature in- 
crease for the Northeast Atlantic is $0.5-1.5^{\circ} \mathrm{C}$ by 2070 . Warming at the poles is expected to be more significant. As the climate warms, snow cover and sea ice extent at the poles will decrease and glaciers and ice caps will lose mass and contribute to a rise in sea level. Sea level rise will continue for centuries or millennia, even if radiative forcing were to be stabilized. The Meridional Overturning Circulation of the North Atlantic (NA-MOC) transports a considerable amount of heat northwards. Most climate models predict a weakening of the NA-MOC during this century due to anthropogenic warming of the high-latitude atmosphere and increased freshwater supply. However, it is very unlikely that the NA-MOC will undergo an abrupt transition during the 21st century. The acidity of the oceans is expected to increase in coming decades. The changes predicted are more rapid than earlier changes within the most recent several thousand years.

\section{Fish stocks and climate.}

In the Northeast Atlantic, a moderate temperature rise in the future is expected to increase the production of cod, haddock and herring. A warming environment is also expected to result in a northward movement of many species. For example, off Norway the distribution of cod, haddock, herring and mackerel are expected to expand northwards, and the spawning areas for cod are likely to move northwards and eastwards in the Barents Sea. Colder water species such as capelin and polar cod will retreat northwards. However, when encountering warming conditions, species distributions may not always exhibit displacement northwards because prey accessibility may change.

The Baltic Sea is expected to become warmer, and the waters fresher, during the course of the $21^{\text {st }}$ century. Thus, marine species will be disadvantaged and more freshwater tolerant species advantaged.

As human-induced climate change increases throughout the $21^{\text {th }}$ century we expect that the northward shift of marine species - from zooplankton to top predators - will continue to increase implying that the abundance of temperate species will continue to increase and the abundance of boreal species will decrease. However, we also expect that these changes will be modified by natural climate oscillations such as the North Atlantic Oscillation (NAO) and the Atlantic Multidecadal Oscillation (AMO) as they have been during the past century.

As $\mathrm{CO} 2$ concentrations in the atmosphere increase, so does ocean assimilation, which, in turn, results in sea water becoming more acidic. This will likely result in a reduction in the area covered and possible loss of coldwater coral reefs, especially at higher latitudes. Ocean acidification will also reduce the biocalcification of other shell-forming organisms such as calcareous phytoplankton which may in turn impact the marine food chain up to higher trophic levels. 
Implications of climate change for capture fisheries and aquaculture.

Climate has direct and indirect effects on the growth, maturation, survival, reproduction and distribution of fish populations, which affect their productivity and resilience. This means that they may no longer be able to sustain the same level of fishing and, therefore, management strategies based oupn biological reference points will have to be adjusted. In some cases, productivity will increase, so the level of fishing could be allowed to rise.

In the Northeast Atlantic and Baltic, there will be winner and loser species. However, there is currently no reason to expect that the overall value of products that can be extracted from the capture fishery, or farmed, will change dramatically. However, climate warming and other concomitant changes in the environment, in addition to the impacts of oil extraction and other intrusive activities, will likely reduce biodiversity which leads to lower resilience.

For all heavily fished stocks, reducing the level of fishing will also offset the effects of climate change. Less fishing activity consumes less fuel and thereby reduces the carbon footprint of the industry (mitigation) while maintaining catches as fish biomass increases.

Unlike wild fish stocks, farmed organisms are locked in to specific locations. As a consequence, optimal farming conditions for the species common in Nordic aquaculture today will gradually move northwards. Current sites will in turn be suitable for other species, for example those presently farmed in Southern Europe. Examples of species that may be more important in Nordic aquaculture in the future are turbot, sea bass, sea bream, oysters and scallops. However, along with increased temperature and new species comes the possibility of disease outbreaks. There will likely be no significant negative effect of climate change on overall aquaculture production in the Northeast Atlantic.

\section{National-transnational implications of climate change.}

Management decisions appear to play a more significant role than possible impacts of global warming on some fisheries. This may be particularly true for the most heavily exploited populations for which several contries share quotas. Developing adaptive, dynamic indicators utilised by proper harvest control rules may be the most adequate strategy for preparing for the consequences of global warming in fisheries.

\section{Policy implications of climate change.}

Climate change - when viewed as an added stress on fish populations and the ecosystems that support them - is associated with increased uncertainty. According to the precautionary approach, we therefore have to reduce risk, which translates into larger margins of safety and smaller 
quotas. Capacity reduction in the fishing fleet will reduce CO2 emissions, as will improvements in vessel efficiency (mechanical). In the perspective of resource management, this is a win-win situation: a reduction in capacity may reduce effort, which is beneficial for conservation of resources, and reduces emissions of climate gases.

\section{Management-relevant conclusions.}

For marine policy and fisheries management authorities, changes in fish stock production, distribution and migrations may imply substantial challenges. The biological production of marine ecosystems may be affected such that the potential for harvest from marine fish populations may have to be revised, and the reference points used to guide management may change as a result. Marine ecosystems will be affected, and this will have implications for the implementation of an ecosystem approach to fisheries. The rapid changes, which may be unpredictable in detail, mean that marine policy and fisheries management increasingly must change to adaptive/precautionary approaches, which has important implications for decision making and its scientific underpinning. The balance of species within the domain of the regional fisheries management organizations may shift, and the total allowable catch (TAC) partitioning between coastal states may have to be renegotiated.

Following from this, there is a need to design monitoring strategies to detect critical changes in species and ecosystems; implement responsive management which can adjust quickly; identify species and ecosystems which are sensitive to changes in climate; anticipate changes in distribution and prepare responses which avoid management conflicts; maintain (or rebuild) resilience of marine ecosystems and fish stocks; understand the socio-economic consequences of climate change on fisheries. The research that is required to form the basis for the preceding must be interdisciplinary and ecosystem based.

Currently, the fisheries and marine science sectors in the Nordic countries are underfinanced and unable to expand their activities to accomplish what is requested of them in the context of ecosystem based management and global climate change. 


\title{
Welcoming remarks and introductions
}

\author{
Ole Arve Misund \\ Research Director \\ Institute of Marine Research \\ POB 1870 Nordnes \\ Bergen, Norway \\ Email: ole.arve.misund@imr.no
}

Dear Minister, Secretary General, Deputy Chair of the City Government, Ladies and gentlemen,

On behalf of the Norwegian Ministry of Fisheries and Coastal Affairs, the EU Commission, Directorate General for Fisheries and Maritime Affairs, and the Nordic Council of Ministers, it is my pleasure and privilege to welcome you to Bergen, and to contribute to this conference on Fisheries Management and Climate Change in the NE Atlantic and in the Baltic Sea. My name is Ole Misund, and I am one of the Research Directors at the Institute of Marine Research (IMR), Norway.

The IMR was tasked with organizing this Conference during a seminar between the Norwegian Ministry of Fisheries and Coastal Affairs and the EU Directorate General for Fisheries and Maritime Affairs that took place in Northern Norway in September 2007. The title of the seminar in Northern Norway was no less than "Visions for a future European fishery policy", and one of the sessions was on climate change and environmental interactions with the fishery. By coincidence, the Nordic Council of Ministers had been planning to organize a conference on this same topic and so we were pleased to have them join forces with us in convening this one.

The objective of this two day Conference is to exchange knowledge and to foster discussions and interactions such that our fisheries management authorities will be better prepared for the implications of climate change.

In a city of culture such as Bergen, it is appropriate to open the Conference with a recital by the "Kor I Havet" (Choir in the Sea) under its conductor Tora Sofie Haarr. The singers are members of the staff of the Directorate of Fisheries, the Norwegian Institute of Nutrition and Seafood Research, and IMR. They will share two songs with us. 
I now introduce you to the Managing Director of IMR, Mr. Tore Nepstad, who will welcome you all to the Conference.

We are very pleased to have with us the Deputy Chair of the City Government in Bergen, Mrs. Lisbeth Iversen, who will welcome us all to the Conference on behalf of the City.

Now it is at great pleasure to introduce one of the Conference hosts, Mrs. Helga Pedersen, Norwegian Minister of Fisheries and Coastal Affairs. Minister Pedersen will deliver the Opening Address.

Finally, it is a great pleasure to introduce another Conference host, the Secretary General of the Nordic Council of Ministers, Mr. Halldòr Asgrimsson, who will deliver an Opening Address.

The Conference is now properly and formally opened.

\section{Welcoming remarks}

\section{Director Tore Nepstad \\ Institute of Marine Research \\ Minister, Secretary General, Dear colleagues}

It is a great pleasure for me to wish you all welcome to Bergen on behalf of Institute of Marine Research. I suppose you already have noticed that this town, and especially the area where we are now, are an area where the effects of climate change with a rice of the sea level will have a great impact. We have already experienced seawater coming into the first floor of the buildings along the Bryggen and the prognosis tell us that this will happen more often in the years to come. This is of course a matter of great concern to people living here.

The agenda of this conference pinpoints important areas of responsibility for the Institute of Marine Research. We have made a structural change in the organising of our institute to meet the requirements for more ecosystem based advise to the management. Therefore, the topics related to climatic changes and the impact of such changes on the marine environment, the marine resources and the future for a sustainable aquaculture industry have our high priority. Through the processes of understanding more of the biological mechanisms and how the different processes in nature interacts, we have learnt that putting together scientists with different experience from different scientific fields have made us ask new questions and it may even have given us new answers.

My hope for this conference is that it will inspire us to ask new questions, to listen and reflect on the information our speakers share with us and that this new knowledge and the discussion we will have during these two days will bring us some steps forward in our work. 
I've been looking forward to meet you here and I'm glad that you took time to come here. Welcome to the conference.

\section{Opening address}

Mrs. Helga Pedersen

Minister of Fisheries and Coastal Affairs

Ministry of Fisheries and Coastal Affairs

Oslo, Norway

Ladies and Gentlemen, it is a great pleasure for me to open this conference on Fisheries Management and Climate Change.

Apart from a diminishing handful of sceptics, there is a worldwide scientific consensus on the scope of the problem, signalizing the following facts:

- climate change is driven by human activity

- climate change is affecting our environment

- climate change requires urgent action

The Government has stated that Norway shall take responsibility and press for a more comprehensive and ambitious climate agreement to succeed the Kyoto. Norway will participate in reducing the emissions of greenhouse gases.

According to meteorological and oceanographic data, an ongoing climate change is increasingly evident also in our marine environment:

- the sea temperature is increasing

- the sea level may rise

- Arctic sea ice is likely to disappear

- weather patterns will become more extreme

Climate change will affect the physical, biological and biochemical characters of the oceans. These changes will become an issue for fisheries, aquaculture and related industry along our coast.

The rapid change, which may be unpredictable in detail, implies that marine policies and fisheries management increasingly must change to adaptive approaches. The approaches have important implications for decision making and its scientific underpinning.

It therefore pleases me that the Norwegian Ministry of Fisheries and Coastal affairs, the EU Commission, Directorate General for Fisheries and Maritime Affairs, and the Nordic Council of Ministers together have 
taken the initiative to prepare the fisheries management authorities for the coming implications of climate change.

Fishery

There are obvious relationships between climate change and variations in fish stocks.

We do know that the occurring climate change will affect the recruitment, growth and distribution of fish stocks.

We do not know whether the effects may be positive or negative, but either way, they are difficult to quantify.

In the Barents Sea fish stocks are expected to expand their feeding grounds towards the northeast. An influx species like mackerel may lead to competition for food with capelin and herring.

In the North Sea an increase in temperature could lead to the migration of species from more southern waters. Sardines and anchovies may become more common. The total amount of fish may not necessarily decrease, but changes could nevertheless affect the commercial value of catches.

The balance of species within the domain of the regional fisheries management organization may shift, and thus it will be an open question if present shares amongst states shall be maintained or will have to be renegotiated. This is only one of many emerging management challenges.

\section{Aquaculture}

Climate changes will also pose challenges for the aquaculture industry. Unlike wild fish, farmed fish are unable to avoid climate change by changing their distribution pattern. Diseases in our aquaculture production traditionally occur during summer and early autumn. An increase in sea temperature therefore affects the likelihood of diseases. Fish health and welfare will therefore represent new scientific challenges.

It is therefore important to fisheries management to secure our domesticated species an optimum environment. If this is not possible, current sites may have to be reconsidered due to temperature increase, but also due to more extreme weather conditions.

With this in mind, it is very important to maintain and strengthen focus on preventing escape in the aquaculture industry.

\section{Coastal communities and fish industry}

New species in fisheries, aquaculture and the related land-based fish processing industry are giving rise to a new situation and challenges related to reorganization. 
More extreme weather conditions may also affect the safety of fishers and those who tend to fish farms. If coastal stocks move to more open waters, this will obviously have consequences for smaller vessels. This may lead to unstable supplies to the fish processing industry and thereby less work for employees.

Climate changes will therefore affect people and businesses along the coast. The necessary adaptations will be costly for businesses and individuals in the shape of investments in equipment, training and marketing.

But - just as science and technology has given us the evidence to measure the danger of climate changes, it may also help us find solutions to the problem.

With regards to developing opportunities for carbon binding and renewable energy, we may exploit the huge expanse of the ocean.The content of nutrients in the coastal current may be used to cultivate organisms related to carbon binding and the production of bio-energy. With the right framework for action, may be combined with economic activity and industrial development along our coast.

\section{Actions}

But - We have to emphasize actions. Action is the cure, and adaptation is only a painkiller. With such focus we can help to secure our environment, biodiversity, the small communities and related infrastructure - not only in Norway, but throughout the coastal communities of the world.

While we are awaiting such a deal, everybody needs to think seriously, not only about adaptation, but also prevention, that means substantial cuts in emissions.

The question is what we can do to reduce $\mathrm{CO} 2$ emissions. In the fisheries and aquaculture sector it is primarily the fishing fleet that is responsible for greenhouse gas emissions. These emissions are in percentage small, but they are possible to reduce. It concerns small and large changes - better propellers, optimum speeds, energy recycling, developments in fisheries technology, ship designs and alternative fuel, such as gas.

It is therefore very encouraging that the fishers' special interest organizations in Norway have taken the initiative to cooperate with the ministry on solutions that can reduce fuel consumption and thereby stimulate reductions in emissions from the fishing fleet.

By reducing greenhouse gas emissions we do not only have the opportunity to slow global warming, we also have the opportunity to satisfy the increase in demand for climate friendly products.

Surveys in Sweden and Great Britain show that a majority of consumers prefer products with ecolabels. In the ecolabel category the "carbon footprint" of products has also become a concept.

I believe that fish, caught with environmentally friendly vessels and equipment, will compare well to other products. Products from fishing 
vessels and fish farms that can document low emissions may have competitive advantages in markets that are increasingly environmentally conscious on climate friendly behaviour.

\section{Conclusion}

No one can be certain about the future. Uncertainty therefore poses great challenges to finding a basis for good decisions. Fisheries management must contribute to this basis by continuing the long term monitoring of the environment and resources.

The Norwegian fishery management is based on such monitoring and related approved research activity. Viewed in this light, we can adapt to the coming changes.

The objectives shall continue to be ecosystem-based management and sustainable harvesting of our resources both under existing and future climate regimes.

We therefore need your experience, ideas and initiatives to address our common challenge - together. This conference and your contribution is very important.

Good luck! I wish you fruitful discussions.

Thank you for your attention.

\section{Opening address}

\section{Mr. Halldór Ásgrimsson \\ Secretary General \\ Nordic Council of Ministers}

Distinguished delegates, Minister of Fisheries Helga Pedersen, politicians, representatives of the fishing industry and researchers.

It gives me great pleasure to open this conference on Climate Change and Fisheries Management - particularly because I know Bergen well, and cherish such fond memories of the time I spent here as a student.

The conference addresses one of the greatest challenges of our time, and one that is of great personal interest to me as a former fisheries minister in Iceland.

At the moment - and especially since the most recent ICCP report was published - public interest in the challenges we face to control and reduce the impact of human activity on the climate is high and increasing all the time. The global community is now engaged in an intensive process of negotiating to replace the Kyoto Protocol on greenhouse gas emissions, a 
process that we hope will culminate in a progressive new agreement at the UN Climate Conference in Copenhagen in December 2009.

The issues we are here to debate feature high on the Nordic agenda. Last week in Riksgränsen, the Swedish Prime Minister hosted the first Nordic Globalisation Forum. The declaration issued by the prime ministers to mark the occasion stated that climate and energy issues are closely related to the challenges of globalisation. They would like the Nordic Region to lead the way on climate-related issues, and have started to work closely together to promote a positive outcome at the 2009 Copenhagen Conferance. The prime ministers have also launched several initiatives designed to improve co-operation on climate- and energy-related research. One of those initiatives aims to examine the impact of climate change on the primary industries. As this is also the theme of our conference, I hope that what we achieve here will be also benefit future Nordic work on the issue.

Although we are working towards global agreement on reducing emissions after the Copenhagen Conferance in 2009, it is obvious that climatic conditions are already beginning to change. Air temperatures have risen - globally and locally - and research indicates that this will have particularly grave consequences for the Arctic - in other words, for our part of the world.

In the course of the next two days, we will look at marine problems related to climate change. I believe that greater emphasis should be placed on the sea in this debate. The oceans are of far greater significance to global climatic conditions than many people realise. Researchers estimate that burning fossil fuels since the Industrial Revolution has pumped 400 gigatonnes (that's 400 billion tonnes!) of $\mathrm{CO}_{2}$ into the atmosphere, of which around $30 \%$ has been absorbed by the oceans. A significant proportion of the heath caused by $\mathrm{CO} 2$ emitted into the atmosphere has been absorbed by the oceans, which has had a cooling effect on the atmosphere.

In other words, the oceans act as important climate stabilisers.

Unfortunately however, the latest research also shows that they are beginning to react to $\mathrm{CO}_{2}$ emissions. Sea temperatures are rising, $\mathrm{pH}$ values goes the opposite way. Forecasts indicate that we can expect the median temperature of the seas to rise by 1-2 degrees Celsius by the end of this century.

It will be interesting to hear what the experts gathered here for this conference have to say about the consequences of such a rise in sea temperature for marine eco-systems and for the North Atlantic fish stocks that are so important to our countries.

The northern European fishing nations are used to natural variations in the size and distribution of fish stocks. Our fishing communities have generations of experience in adapting to new circumstances - the bestknown example being the shift in Greenland about forty years ago from 
concentrating on cod to fishing exclusively for prawns. Should we expect more of similar changes in the future?

Many of the big fish stocks that live in the open waters of the North Atlantic are subject to joint management by the appropriate governments. It will be interesting to hear a commercial perspective on changes in the migration patterns of these extremely mobile stocks - and also particularly fascinating to hear the views of the representatives from regional fisheries organisations on the management of fish stocks that are shared by multiple nations, and which will change in size and distribution all the time.

This conference is a fine example of the strong tradition of cooperation between the EU, the Nordic Region and the largest Nordic fishing nation, Norway. Co-operation between the Nordic Council of Ministers and the EU on marine issues is crucial. We now have number of positive experience of working together on a variety of topics, and I feel sure that both parties will continue to benefit from collaborating on marine issues in the future - particularly since EU policy covers a number of areas that are extremely topical in Nordic co-operation at the moment.

Climate change is a top priority in the programme for the Swedish Presidency of the Nordic Council of Ministers 2008, so this conference is also an important element in the Presidency's fisheries programme.

The oceans also find themselves at the top of the global climate agenda. During his visit to the Faroes and Iceland last week, former American Vice-President Al Gore highlighted climate issues, particularly in relation to the sea. This helped raise awareness. Today we are in Bergen, one of the most important Nordic fishing ports, and home to one of the world's leading marine-research institutions. However, climate change cannot be tackled by awareness alone - we must engage the world's leading researchers in the task of gaining a better understanding of what is happening now, what will happen next, and how best to react to change.

I hope that this conference will help provide answers to some of the many questions associated with this important theme. I also hope it will help identify issues where more work needs to be done - by researchers and by official bodies - and that it will encourage greater European and Nordic input on these pressing issues.

I wish you all a successful conference. 


\title{
Part 1. Changes in Climate, Fish Stocks and Aquaculture.
}

Changes in Ocean Climate. Convener: Ole Arve Misund, Institute of Marine Research, Norway

\section{The IPPC scenarios for climate change}

\author{
Inger Hanssen-Bauer
}

Norwegian Meteorological Institute

Gaustadalleen 30D

Oslo, Norway

Email: ingerhb@met.no

Some highlights from the IPCC $4^{\text {th }}$ assessment report (IPCC AR4) are presented, with an emphasis on robust findings and key uncertainties. Global climate models have been improved substantially since the first IPCC assessment, both in complexity, parameterisation and spatial resolution. The models are quite successful in modelling the observed climate variability of the $20^{\text {th }}$ century when both natural and anthropogenic forcing are taken into account.

Modelling of $20^{\text {th }}$ century climate. Robust findings:

- Most of the observed increase in global average temperatures since the mid-20th century is very likely due to the observed increase in anthropogenic greenhouse gas concentrations.

Modelling of future climate. Robust findings:

- For the next two decades, a warming of about $0.2^{\circ} \mathrm{C}$ per decade is projected for a range of emission scenarios.

- Continued greenhouse gas emissions at or above current rates would cause further warming during the 21st century that would very likely be larger than those observed during the 20th century.

- Projected temperature increases are greater at high northern latitudes and over land, with less warming over the southern oceans and North Atlantic. 
- Temperatures averaged over all habitable continents will very likely rise at greater than the global average rate, and by an amount substantially in excess of natural variability.

- Precipitation generally increases in the tropical maximum zone, decreases in the subtropics and increases at high latitudes as a conesquence of a general intensification of the global hydrological cycle. Precipitation is very likely to increase in northern Europe, the northeast USA and the Arctic.

- Heat waves become more frequent and longer lasting in a future warmer climate.

- Decreases in frost days almost everywhere in the mid- and high latitudes, with an increase in growing season length.

- Tendency for summer drying of the mid-continental areas, indicating a greater risk of droughts.

- Extremes of daily precipitation are likely to increase in many regions and very likely to increase in northern Europe

- Based on current simulations, it is very likely that the Atlantic Ocean Meridional Overturning Circulation (MOC) will slow down by 2100. However, it is very unlikely that the MOC will undergo an abrupt transition during the course of the 21st century.

- As the climate warms, snow cover and sea ice extent decrease and glaciers and ice caps lose mass and contribute to a rise in sea level. Sea ice extent decreases in the 21st century in both the Arctic and Antarctic.

- Sea level rise due to thermal expansion and loss of mass from ice sheets would continue for centuries or millennia even if radiative forcing were to be stabilized.

- Projected warming during the 21 st century will continue to contribute to sea level rise for many centuries.

- Sea level rise was not geographically uniform in the past and will not be in the future.

\section{Modelling of future climate. Key uncertainties:}

- The likelihood of a large abrupt change in the MOC beyond the end of the 21st century cannot yet be reliably assessed.

- For low/medium emission scenarios, the MOC recovers from initial weakening within one to several centuries, but permanent reduction in the MOC cannot be excluded if the forcing is strong and long enough.

- Large uncertainties remain about how clouds might respond to global climate change.

- Changes in key processes that drive some global and regional climate changes are poorly known (e.g., ENSO, NAO, blocking, MOC, land surface feedbacks, tropical cyclone distribution). 
- The sensitivity of ice sheet surface mass balance (melting and precipitation) to global climate change is not well constrained by observations and there is a large variability in models predictions $\rightarrow$ there is a large uncertainty in the magnitude of global warming that would lead to the elimination of the Greenland Ice Sheet.

- Models do not yet exist that address key processes that could contribute to large rapid dynamical changes in the Antarctic and Greenland Ice Sheets that could increase the discharge of ice into the ocean.

\title{
Ocean climate variations and predictions in the Northeast Atlantic Ocean
}

\author{
Bogi Hansen \\ Faroese Fisheries Laboratory \\ Faroe Islands \\ Email: bogihan@frs.fo
}

The climatic conditions of the Northeast Atlantic have always varied in response to external and internal forcing. Long-term measurements have demonstrated consistent temperature and salinity variations on decadal timescales which, to a large extent, can be understood in terms of variable source waters. The upper layers of the Northeast Atlantic are fed from both the Subtropical and the Subpolar Gyre (SPG) but the relative contributions vary depending on the extent of the SPG, which again depends on convection in the Labrador Sea. Within the Northeast Atlantic, variations in air-sea fluxes and wind forcing induce further variability into the ocean. In addition to these natural variations, the ocean will in the future be affected by anthropogenic climate change, but the resulting changes are hard to predict due to our limited knowledge of the climate system and future greenhouse gas emissions. Except for regions that are now ice covered, ocean areas are generally predicted to experience less warming than continents, and this is especially the case for the North Atlantic. Today, the Meridional Overturning Circulation of the North Atlantic (NA-MOC) transports a considerable amount of heat northwards, but most climate models predict a weakening of the NA-MOC during this century due to anthropogenic warming of the high-latitude atmosphere and increased freshwater supply (IPCC, 2007). The NA-MOC is fed from two main sources: (1) Overflow from the Nordic Seas, and (2) Labrador Sea convection. Which of these two sources will weaken most may determine the future conditions in the Northeast Atlantic. If the overflow were to weaken substantially, the Northeast Atlantic might experience large changes to surface flows, frontal locations, temperature, and salinity distributions. Recent climate models perhaps indicate Labrador Sea convection to be more sensitive to climate change (IPCC, 2007), which is 
consistent with historical evidence. Combining direct current measurements with an atmospherically forced ocean model, the most recent evidence indicates that the overflow did not weaken from 1948 to 2005, but Labrador Sea convection has been reduced since the mid-1990s. Climate models are, however, not yet at a stage where quantitative estimates of NA-MOC weakening or its regional impacts can be given with any high level of confidence. In the Northeast Atlantic, future hydrographic conditions, current flows, and frontal locations remain uncertain. Combined with uncertainties in the future atmospheric forcing and the complexities of marine ecosystems, this makes predictions of Northeast Atlantic fish stocks difficult. Most likely, they will experience large changes, but which? 


\section{Part 1. Changes in Climate, Fish Stocks and Aquaculture.}

Fish Stocks and Climate. Convener: Fredrik Arrhenius, Swedish Board of Fisheries, Gothenburg, Sweden

\section{Predictions of changing fish stock production, distribution and migrations in the Northeast Atlantic}

Randi Ingvaldsen, Svein Sundby, Ken Drinkwater and Jan Erik Stiansen Institute of Marine Research

Bergen, Norway

Email: randi.ingvaldsen@imr.no

Marine ecosystems are strongly influenced by climate and fisheries. The physical environment impacts the ecosystem through light, temperature, ocean currents and turbulence. It affects fish both as individuals and as populations. It impacts all layers in the food chain with the strongest impact tending to be in the lower layers, i.e. the plankton. Climate-induced changes in these lower levels can cause changes further up the food chain leading to indirect impacts on fish. As for fish populations, climate impacts recruitment, growth rates and abundance, both directly and indirectly through the food chain, and these aspects will together affect the productivity of populations. In addition, climate impacts the distribution and migration of fish populations.

The ocean climate exhibits natural variability and, since ecosystems are adapted to this variability, they are constantly changing. Warm or cold periods lasting for a few years have strong impacts on individual marine populations, but only limited impacts on the ecosystem as a whole. Longer term changes in climate tend to be of much smaller amplitude than the annual variability, but the impacts are often much stronger causing large-scale changes in the entire ecosystem and, thereby, the fisheries. The observed long-term natural variability in ocean temperature in the Barents Sea since 1900 has an amplitude of about $0.7^{\circ} \mathrm{C}$. The predicted temperature increase for the Northeast Atlantic is $0.5-1.5^{\circ} \mathrm{C}$ by 2070, indicating that profound changes in the ecosystems and the fisheries may be expected.

Future predictions on fish populations under a changing climate can be made through a combination of analysing the observed changes in former warm and cold periods, from dynamic models of biological pro- 
duction and by studying ecosystem relations. A moderate temperature rise in the future is expected to increase the production of cod, haddock and herring. A warming environment is also expected to result in a northward movement of many species. For example, off Norway the distribution of cod, haddock, herring and mackerel are expected to expand northwards, and the spawning areas for cod are likely to move northwards and eastwards in the Barents Sea. These changes are already occurring. Colder water species such as capelin and polar cod will retreat northwards. However, when encountering warming conditions, species distributions may not always exhibit displacement northwards because prey accessibility may change. Climate-induced change modifies the ecosystem and, therefore, projections into a warmer future must take into consideration changes in ecosystem function.

\title{
Impact of $21^{\text {st }}$ century climate change on the Baltic Sea fish community and fisheries
}

\author{
Brian R. MacKenzie \\ National Institute for Aquatic Resources \\ Technical University of Denmark (DTU-Aqua) \\ and \\ University of Aarhus \\ Kavalergården 6 \\ DK-2920 Charlottenlund \\ Denmark \\ Email: brm@aqua.dtu.dk
}

The Baltic Sea is a large brackish semi-enclosed sea whose species-poor fish community supports important commercial and recreational fisheries. Both the fish species and the fisheries are strongly affected by climate variations. These climatic effects and the underlying mechanisms are briefly reviewed. Recent regional-scale climate - ocean modelling results are then used to consider how climate change during this century will affect the fish community of the Baltic and fisheries management.

Some of the world's longest calibrated daily time series have been produced in the Baltic and North Seas. These data show that trends in surface temperatures in the area now exceed those at any time since instrumented measurements began in 1861 and 1880 . Temperatures in summer since 1985 have increased at nearly triple the global warming rate which is expected to occur during the $21^{\text {st }}$ century and summer temperatures have risen 2-5 times faster than those in other seasons. These warm temperatures and rates of change are due partly to an increase in the frequency of extremely warm years. The recent warming event (since 1985) is exceeding the ability of local species to adapt and is consequently lead- 
ing to major changes in the structure, function and services of both ecosystems.

Looking to the future, expected climate changes in northern Europe will likely affect not only the temperature, but also the salinity, of the Baltic Sea, causing it to become warmer and fresher. As an estuarine ecosystem with large horizontal and vertical salinity gradients, biodiversity will be particularly sensitive to changes in salinity which can be expected as a consequence of altered precipitation patterns. Marine-tolerant species will be disadvantaged and their distributions will partially contract from the Baltic Sea; habitats of freshwater species will likely expand. Although some new species can be expected to immigrate because of an expected increase in sea temperature, only a few of these species will be able to successfully colonize the Baltic because of its low salinity. The effects of climate change will also interact with ongoing eutrophication problems in the Baltic Sea and could exacerbate existing environmental stress on reproduction and recruitment of species such as cod. Fishing fleets which presently target marine species (e. g. cod, herring, sprat, plaice, sole) in the Baltic will likely have to relocate to more marine areas or switch to other species which tolerate decreasing salinities. Fishery management thresholds that trigger reductions in fishing quotas or fishery closures to conserve local populations (e. g. cod, salmon) will have to be re-assessed as the ecological basis on which existing thresholds have been established changes, and new thresholds will have to be developed for immigrant species. The Baltic situation illustrates some of the uncertainties and complexities associated with forecasting how fish populations, communities and industries dependent on an estuarine ecosystem might respond to future climate change.

Further information is available in the following two publications:

MacKenzie BR, Schiedek D (2007) Daily ocean monitoring since the 1860s shows unprecedented warming of northern European seas. Glob.Change Biol., 13, 1335-1347 (doi:10.1111/j.13652486.2007.01360.x).

MacKenzie BR, Gislason H, Möllmann C, Köster FW (2007) Impact of 21st century climate change on the Baltic Sea fish community and fisheries. Glob.Change Biol., 13, 1348-1367 (doi:10.1111/j.13652486.2007.01369.x). 


\title{
Climate change impacts on the marine ecosystems of the North Sea and west of the British Isles
}

\author{
Svein Sundby \\ Institute of Marine Research/Bjerknes Centre for Climate Research \\ P.O. Box 1870 Nordnes \\ N-5817 Bergen \\ Norway \\ Email:svein.sundby@imr.no
}

The marine ecosystems of the North Sea and the region to the west of the British Isles are associated with marine ecosystems which range from temperate regimes in the south to boreal regimes in the north. The North Atlantic, including the North Sea and the seas around the British Isles, has experienced climate variability over a range of various periodicities with various amplitudes during the $20^{\text {th }}$ century.

The periodicity of the climate signal is linked to the spatial scale of the signal. Interannual climate variations have a typical spatial extent limited to the size of the regional sea areas, e.g. the North Sea and the seas around the British Isles. The Norwegian Sea shows a different interannual variability, and the Barents Sea another kind of interannual variability. The decadal-scale climate signal, associated with the North Atlantic Oscillation (NAO) has a larger spatial extent typically associated with the entire northeast Atlantic comprising the North Sea, the Baltic Sea, the Norwegian Sea and the Barents Sea in concert. The multidecadal climate signal, associated with the Atlantic Multidecadal Oscillation (AMO), has an even larger spatial extent covering the entire North Atlantic Ocean.

The decadal-scale signal, like the NAO, and the multidecadal signal, the AMO, are the two most prominent climate signals with respect to impacts on the marine ecosystems in the North Atlantic. The decadalscale signal influences the ecosystems in a number of ways, particularly the processes linked to recruitment in fish and zooplankton abundance. The multidecadal signal has lower amplitude than the decadal-scale signal. Nevertheless, the multidecadal signal has had a substantially larger ecosystem impact than the decadal-scale signal. This indicates that the persistence of the climate signal can be more important than the amplitude. In addition to the decadal signal, important influences from the multidecadal climate signal are on habitat extents through the entire food web from plankton to top predators.

The decadal-scale NAO signal is strong enough to influence the current systems of the northeast Atlantic. Thus, changes in the transport of important plankton species are influenced by the NAO. This in turn influences recruitment and growth in fish stocks.

The multidecadal AMO climate signal has a more large-scale impact on the entire North Atlantic. During the 1900 to 1920s the AMO was 
dominated by cool conditions, thereafter temperature increased towards the 1930s and it continued to be warm until the 1950s. During the 1960s and 1970s a new cool event occurred. This event was again succeeded by the recent warming which started in the mid 1980s. As the North Sea and the waters around the British Isles are located in the transition zone between temperate and boreal conditions the climate shifts throughout the $20^{\text {th }}$ century have swapped between temperate-dominated ecosystems to boreal-dominated ecosystems. This has substantially influenced species composition, abundance and habitat ranges of the organisms from zooplankton to top predators of the region. During warm events zooplankton is more dominated by temperate copepod species like Calanus helgolandicus and among the fish species anchovy and sardine become abundant. During cool events the boreal copepod Calanus finmarchicus dominates and the associated fish species are also boreal, like cod, haddock, herring and mackerel. The boreal species are mainly adapted to a spring bloom ecosystem with high phytoplankton production in spring and early summer, while the temperate species are associated with extended phytoplankton blooms throughout the year.

As human-induced climate change increases throughout the $21^{\text {th }}$ century we expect that the northward shift of marine species from zooplankton to top predators will continue to increase implying that the abundance of temperate species will continue to increase and the abundance of boreal species will decrease. However, we also expect that these changes will be modified by natural climate oscillations like the NAO and AMO as they have been during the past century. 



\title{
Part 2. Implications of Climate Change.
}

Capture Fisheries and Aquaculture Implications. Convener: Poul Dengbol, EU Commission, Belgium

\section{In Dead Water}

\author{
Peter Prokosch \\ UNEP/Grid \\ Arendal, Norway \\ Email: peter.prokosch@grida.no
}

\section{Summary}

The World's oceans play a crucial role for life on the planet. Healthy seas and the services they provide are key to the future development of mankind. Our seas are highly dynamic, structured and complex systems. The seafloor consists of vast shelves and plains with huge mountains, canyons and trenches which dwarf similar structures on land. Ocean currents transport water masses many times larger than all rivers on Earth combined.

In this report, the locations of the most productive fishing grounds in the World - from shallow, coastal waters to the deep and high seas - are compared to projected scenarios of climate change, ocean acidification, coral bleaching, intensity of fisheries, land-based pollution, increase of invasive species infestations and growth in coastal development.

Half the World catch is caught in less than $10 \%$ of the ocean

Marine life and living resources are neither evenly nor randomly distributed across the oceans. The far largest share of marine biodiversity is associated with the sea bed, especially on the continental shelves and slopes. Seamounts, often rising several thousand meters above their surroundings, provide unique underwater oases that teem with life. Environmental parameters and conditions that determine the productivity of the oceans vary greatly at temporal and spatial scales. The primary and most important fishing grounds in the World are found on and along continental shelves within less than 200 nautical miles of the shores. The distribution of these fishing grounds is patchy and very localized. Indeed more than half of the 2004 marine landings are caught within $100 \mathrm{~km}$ of 
the coast with depths generally less than $200 \mathrm{~m}$ covering an area of less than $7.5 \%$ of the world's oceans, and $92 \%$ in less than half of the total ocean area. These treasure vaults of marine food play a crucial role for coastal populations, livelihoods and the economy. Whether they will provide these functions and services in the future depends on needed policy changes and the continuation of a number of environmental mechanisms to which marine life has evolved and adapted. These natural processes include clean waters with balanced temperature and chemistry regimes as well as currents and water exchanges that provide these areas with oxygen and food, to name just a few. However, there are alarming signals that these natural processes to which marine life is finely attuned are rapidly changing.

With climate change, more than $80 \%$ of the World's coral reefs may die within decades

In tropical shallow waters, a temperature increase of up to only $3^{\circ} \mathrm{C}$ by 2100 may result in annual or bi-annual bleaching events of coral reefs from 2030-2050. Even the most optimistic scenarios project annual bleaching in $80-100 \%$ of the World's coral reefs by 2080 . This is likely to result in severe damage and wide-spread death of corals around the World, particularly in the Western Pacific, but also in the Indian Ocean, the Persian Gulf and the Middle East and in the Caribbean.

Ocean acidification will also severely damage coldwater coral reefs and affect negatively other shell-forming organisms

As CO2 concentrations in the atmosphere increase so does ocean assimilation, which, in turn, results in sea water becoming more acidic. This will likely result in a reduction in the area covered and possible loss of coldwater coral reefs, especially at higher latitudes. Besides cold water corals ocean acidification will reduce the biocalcification of other shellforming organisms such as calcareous phytoplankton which may in turn impact the marine food chain up to higher trophic levels.

Coastal development is increasing rapidly and is projected to impact 91\% of all inhabited coasts by 2050 and will contribute to more than $80 \%$ of all marine pollution

Marine pollution, more than $80 \%$ of which originates from land-based sources, is projected to increase, particularly in Southeast and East Asia, due to rising population and coastal development. Increased loads of sediments and nutrients from deforestation, sewage and river run-off will greatly diminish the resilience of coral reefs. The effects of pollution are exacerbated by the destruction of mangroves and other habitats due to the rapid construction taking place on coastlines. As much as $91 \%$ of all temperate and tropical coasts will be heavily impacted by development by 2050. These impacts will be further compounded by sea level rise and the 
increased frequency and intensity of storms that easily break down weakened or dead corals and are likely to severely damage beaches and coast lines.

Climate change may slow down ocean thermohaline circulation and continental shelf "flushing and cleaning" mechanisms crucial to coastal water quality and nutrient cycling and deep-water production in more than $75 \%$ of the World's fishing grounds

Of major concern is that many of these productive fishing grounds depend extensively upon sea currents for maintaining life cycle patterns for the sustainable production of fish and other marine life. Large scale water exchange mechanisms, which periodically "flush and clean" continental shelf areas, are observed in and near at least ca. 75\% of all the major fishing grounds. These mechanisms, however, depend entirely on cooler and heavier seawater sinking into the deep sea, often using and carving channels and canyons into the continental shelf.

New research suggests that while climate change may not necessarily stop the major thermohaline currents, climate change may potentially reduce the frequency of the coastal flushing mechanisms, particularly at lower to medium latitudes over the next 100 years, which in turn will impact both nutrient and larval transport and increase the risk of pollution and dead zones.

Increased development, coastal pollution and climate change impacts on currents will accelerate the spreading of marine dead zones, many around or in primary fishing grounds

The number of dead zones (hypoxic or oxygen deficient areas) increased from 149 in 2003 to over 200 in 2006. Given their association with pollutants from urban and agricultural sources, together with the projected growth in coastal development, this number may multiply in a few decades, unless substantial changes in policy are implemented. Most dead zones, a few of which are natural phenomena, have been observed in coastal waters, which are also home to the primary fishing grounds.

Over-harvesting and bottom trawling are degrading fish habitats and threatening the entire productivity of ocean biodiversity hotspots, making them more vulnerable to climate change

Recent studies indicate that fishery impacts in shelf areas may potentially become even worse in deeper water. Due to advances in technology and subsidies, fishing capacity is now estimated to be as much as 2.5 times that needed to harvest the sustainable yield from the world's fisheries. Up to $80 \%$ of the worlds primary catch species are exploited beyond or close to their harvest capacity, and some productive seabeds have been partly or even extensively damaged over large areas of fishing grounds. With many traditional, shallow fishing grounds depleted, fisheries (especially 
large industrial vessels/fleets operating for weeks/months at sea) are increasingly targeting deep-water species on the continental slopes and seamounts. Over $95 \%$ of the damage and change to the seamounts is caused by bottom fishing, mostly carried out unregulated and unreported with highly destructive gear such as trawls, dredges and traps. Trawling has been estimated to be as damaging to the sea bed as all other fishing gear combined. Unlike only a decade ago, there are now numerous studies from nearly all parts of the world, documenting the severe long-term impacts of trawling. The damage exceeds over half of the sea bed area of many fishing grounds, and worse in inner and middle parts of the continental shelves with particular damage to small-scale coastal fishing communites. Indeed, while very light trawling may be sustainable or even increase abundance and productivity of a few taxa, new studies, including data from over a century ago, clearly indicate damage to the sea bed across large portions of the fishing grounds, and at worst reductions in pristine taxa of $20-80 \%$ including both demersals and benthic fauna. Unlike their shallow water counterparts, deep sea communities recover slowly, over decades and centuries, from such impacts. Some might not recover at all if faced with additional pressures including climate change and might lead to a permanent reduction in the productivity of fishing grounds. There are now discussions ongoing with several bodies including the FAO on developing better international guidelines for the management of deepsea fisheries in the high seas, but substantial action is urgently needed given the cumulative threats that the oceans are facing.

Primary fishing grounds are likely to become increasingly infested by invasive species, many introduced from ship ballast water

The vulnerability of impacted ecosystems to additional stresses is also demonstrated by the increase of invasive species infestations that are concentrated in the same $10-15 \%$ of the Worlds oceans. Heavily disturbed and damaged marine areas are more likely to be much more vulnerable to infestations brought in by ships plying the world's oceans despite recommendations in many areas for mid-ocean exchange of ballast water. Geographical distribution of invasive species suggests a strong relationship between their occurrence and disturbed, polluted and overfished areas and in particular the location of major shipping routes at a global scale. It appears that the most devastating outbreaks of such marine infestations have been brought in along the major shipping routes and primarily established in the most intensively fished and polluted areas on the continental shelves. Growing climate change will most likely accelerate these invasions further. 
The cumulative impacts of climate change with existing pressures of over-harvest, bottomtrawling, invasive species, coastal development and pollution appear to be concentrated at worst in 10-15\% of the oceans concurrent with today's most important fishing grounds

Climate change, with its potential effects on ocean thermohaline circulation and a potential future decline in natural 'flushing and cleaning' mechanisms, shifts in the distributions of marine life, coral bleaching, acidification and stressed ecosystems will compound the impacts of other stressors like overharvest, bottom trawling, coastal pollution and introduced species.

The combined actions of climate change and other human pressures will increase the vulnerability of the world's most productive fishing grounds - with serious ecological, economic and social implications. The potential effects are likely to be most pronounced for developing countries where fish are an increasingly important and valuable export product, and there is limited scope for mitigation or adaptation.

A lack of good marine data and poor funding for ocean observations may have led to greater environmental degradation in the sea than would have been allowed on land

The lack of marine information and easy observation by humans as landliving organisms, along with insufficient funds for monitoring, may result in these and other pressures to progress farther than anything we have yet seen or would have permitted without intervention on land, even though the oceans represent a significant share of global economies and basic food supply. Lack of good governance, particularly of the high seas, but also in many exclusive economic zones (EEZs) where the primary focus is economic gain, and has resulted in limited flexibility or incentive to shift to ecosystem based management. The potential for climate change to disrupt natural cycles in ocean productivity, adds to the urgency to better manage our oceans. The loss and impoverishment of these highly diverse marine ecosystems on Earth and modification of the marine food chain will have profound effects on life in the seas and human wellbeing in the future.

Substantial resources need to be allocated to reducing climate and nonclimate pressures and priority needs to be given to protecting substantial areas of the continental shelves. These initiatives are needed to build resilience against climate change and to ensure that further collapses in fish stocks are avoided in coming decades.

Urgent efforts to control accelerating climate change are needed, but this alone will not be sufficient. A substantially increased focus must be devoted to building and strengthening the resilience of marine ecosystems. Synergistic threats and impacts need to be addressed in a synergistic way, via application of an ecosystem and integrated ocean management ap- 
proach. Actions for a reduction of coastal pollution, establishment of marine protected areas in deeper waters, protection of seamounts and parts (likely at least 20\%) of the continental shelves against bottom trawling and other extractive activity, and stronger regulation of fisheries have all to go hand in hand. Unless these actions are taken immediately, the resilience of most fishing grounds in the world, and their ability to recover, will further diminish. Accelerating climate change and in-action risks an unprecedented, dramatic and wide-spread collapse of marine ecosystems and fisheries within the next decades.

Nellemann, C., Hain, S., and Alder, J. (Eds). February 2008. In Dead Water - Merging of climate change with pollution, over-harvest, and infestations in the world's fishing grounds. United Nations Environment Programme, GRID-Arendal, Norway, www.grida.no

\section{Climate Change and Fisheries in the North Sea and West of Scotland}

\section{Bill Turrell}

Fisheries Research Services

Scottish Government Marine Directive

Email: turrellb@marlab.ac.uk

A better title for this talk might be "Climate Change and Scottish Fisheries", as I look at the climatic and ecological changes that have occurred over the past few decades, principally in the North Sea although conditions west of Scotland have been very similar, and focus on how science, the media and the Scottish fishing industry responded to those changes. I hope that we can take some lessons from this period and apply them to the coming challenges that future climate change will bring.

The talk starts by summarising in a simple way the alterations that have occurred to the food chain in the North Sea as a result of both climatic forcing and fishing pressure. Emphasis is placed on explaining the cod story, as it is this that has driven much of fisheries management in the mixed demersal fisheries which the Scottish industry exploits. The switch from fisheries dominated by demersal, predator fish to one dominated by shellfish (Nephrops) is explained. The different roles climate and fishing pressure have played in this alteration are briefly examined. This is what the ecosystem / fishery system has experienced during the period. The talk goes on to examine how science, the media and industry responded to these changes.

Fisheries science urged caution from an early point, as its sole focus on fish biology including recruitment and fishing mortality alerted it to the impending stresses on cod stocks. However, fisheries science also 
failed to tackle and explain the relevance of other changes occurring at the time due to climate alterations. The wider marine science community focused on individual aspects of the North Sea and north east Atlantic ocean climate and biology. Independently different messages were communicated to the industry, which then focused on very simplistic aspects of the changes occurring, and ignored unpleasant truths such as the high fishing pressure on the stock.

The media throughout the period grew increasingly partisan, and moved from a position where science was well reported to an entrenched position where it was fishing versus climate. Agenda-driven reporting occurred which did nothing to help the industry understand the changes they were experiencing on the fishing grounds. Science itself may have exploited the media by presenting very complex issues in a stark "black and white" way, and not presenting the true complexity of the situation, especially in a complex ecosystem such as the North Sea. One of the reasons for doing this is the increasingly competitive atmosphere surrounding science funding. Nature conservation Non-Governmental Organisations (NGOs) also presented science in extreme ways, in an (understandable) effort to raise public awareness in climate change and the need for mitigation measures.

In this heated atmosphere, industry was left to find its own route through the impending demise of cod. It could not understand why fisheries scientists thought cod was recoverable, when other scientists were seemingly saying the climate made recovery impossible, even though this was not what the science suggested. The Regional Advisory Councils (RACs) helped by bringing scientists, managers and the industry together at the North Sea Cod Symposium where sensible conclusions were reached, that cod was in a poor state but was recoverable. Then, in early 2007, cod began to show signs of recovery. Hence the next phase of the cod and climate story has already begun.

The lessons learnt are plentiful. Marine science needs to embrace the holistic aspects of the ecosystem approach, and get away from the singlediscipline approach which led to different messages coming from fisheries science and ecologists. Scientists must learn how to explain complexity and uncertainty simply so that the industry and managers can understand their implications. At the same time industry needs to become more educated, and less reliant on myths and anecdote. It is now a modern industry which impacts the environment, employing high technology and sophisticated marketing and financing methods. It has to take the same level of sophistication when trying to understand and manage its ecological footprint, and science needs to help with this educational process. We also need a more educated and responsible media, especially in the fishing press, to support and inform the industry in the times ahead. Overall every sector needs honesty in order to tackle the real challenges that will come. 
We are not certain what future climate change will bring, although one thing is certain - change. Certainly within 50 years global warming will mean political emphasis moves away from sustainability and conservation issues to simple yet vital matters such as food and water supply. Between now and then we should work towards an educated, responsible fishing industry that understands the ecosystem it exploits and strives towards sustainability.

\title{
Will the Polar waters become the new fishing grounds?
}

\author{
Konstantin.V. Drevetnyak, Oleg. V. Titov, Yuri. M. Lepesevitch
}

Polar Research Institute of Marine Fisheries and Oceanography (PINRO)

Knipovich-St., 6, Murmansk, 183038, Russia.

Email: drevko@pinro.ru

The objective of the paper is to assess current changes in water temperature in the Barents Sea and adjacent areas, stock status of common commercial species, as well as characteristics of fisheries and its prospects. The Barents Sea is one of the most important fishing areas in the world fisheries, biological productivity of which $\left(800 \mathrm{~kg} / \mathrm{km}^{2}\right)$ is more than three times higher than productivity of the World Ocean $\left(225 \mathrm{~kg} / \mathrm{km}^{2}\right)$. The official world yield of all species in the Barents Sea and adjacent waters in the post-war period (1947-2005) amounted to nearly114 million tonnes, and the mean annual catch made up 1.94 million tonnes. In the period 1947-1977 it increased from 1 to 4.47 million tonnes. After 1977 it decreased dramatically and during the recent decade (1995-2005) stabilized at the level of about 1.2 million tonnes. Total catch in the Barents Sea was dominated by capelin (48\%) and cod (31\%). Then, in descending order, it comprised saithe (8\%), haddock (6\%) and redfishes (4\%).

In warm years primary production in the Barents Sea is increased. This is a favourable condition for migration of warm-water fish species to the Barents Sea from southern areas and for a higher survival of juvenile Barents Sea fishes. Climate warming contributes to a wider distribution of target species over the sea area, which leads to better conditions of their feeding, an increase of growth rate, accumulation of fat and better quality of reproductive products and, eventually to increase in survival and abundance of posterior year classes.

Current changes of climate even now have a noticeable impact on living marine resources in the Barents Sea and adjacent waters. Many species belonging to boreal faunistic complex including common pelagic species such as Atlantic herring, saithe and blue whiting now are encountered more often in the Barents Sea. 
An increase in abundance and biomass of blue whiting was observed in the Barents Sea in 2000's. In the northern areas in spring and summer the blue whiting fed actively on polar cod and capelin, as well as on juvenile cod, haddock and redfish. At present, because of the depression of the blue whiting stock its abundance has decreased dramatically, however under the condition that the blue whiting stock will be recovered up to the previous level and trends in temperature of the sub-arctic waters will be kept, the blue whiting predation may have a pronounced effect on the stock state of the Barents Sea species. Reduction in stocks of the common pelagic species in the Barents Sea resulting from the blue whiting predation may in its turn have an adverse impact on cod feeding and entail shifts in seasonal biological cycle of cod followed by changes in reproductive function of the population.

Warming in the Barents Sea also has an influence on the length of migration of commercial species and their fishing grounds. In 2006-2007, high catches of cod by Russian fishing vessels were taken during long period of time in the utmost northeastern areas of its habitat, where, prior to the above mentioned period, cod were observed only occasionally and did not form fishable concentrations. Unfortunately, we do not have data available on distribution of cod concentrations in these areas in the period of maximum warming of the Barents Sea in the 1930's.

In 2000's, the intensity of the Russian fishery for haddock in the northwestern Barents Sea increased sharply. While previously the percentage of haddock catch in this area did not exceed 3\%, in 1999-2007 it increased up to $15 \%$, and annual catch averaged about 6.5 thousand tonnes. In our opinion, it is possible that in 2008-2009 the situation may be repeated similar to that observed in the haddock fishery in 1975, when they were largely harvested in autumn in the West and North Spitsbergen waters between $79^{\circ}$ and $80^{\circ} \mathrm{N}$. Healthy fishable and spawning stocks of haddock, and retention of increased heat content of the sea in the northwestern areas, determine a fairly high probability of such fishery.

The impacts of warming extend not only to fishing areas and formation of the gadoids abundance. They may have far-reaching implications also for such commercially important species as redfish and Greenland halibut. It is known that their larvae are adapted to spending a part of the life span under low temperatures in high latitudes of the Arctic, where the effect of predation is minor, due to which they have an advantage of survival over typically boreal species owing to their low mortality from predation. Active penetration of blue whiting into the Barents Sea and their migration to the west of Spitsbergen as well as further shifts of cod feeding areas towards the north may radically change this situation and result in an increase in mortality of redfish and Greenland halibut resulting from predation.

Continuation and possible intensification of global warming give strong grounds to consider prospects of fisheries in those areas of the sea 
which earlier were not of commercial importance, in particular in the Kara Sea and at the boundary of the Barents and Kara Seas. Scientific literature and archived data of PINRO indicate that in anomalously warm 1930's, as well as in warm 1950's in the adjacent areas of the Barents and Kara Seas the occurrence of cod in catches was observed to increase. There is also information about capelin spawning in the southwestern part of the Kara Sea in August-September and about large discards of postspawning fish over tens of kilometers along the northwestern areas of the Baidaratskaya Guba coast.

During research carried out by PINRO in the Kara Sea in AugustSeptember 2007 fishable concentrations of polar cod were found at the southern and northern extremities of the Novaya Zemlya. In the west, the warmest areas of the Kara Sea, catches comprised cod, haddock and capelin. In the north of the Kara Sea and at its boundary with the Barents Sea, during bottom tows Greenland halibut occurred almost everywhere and catches were dominated by middle-sized individuals of 35-45 cm in length. Probably, the absence of predators and availability of sufficient food resources provide good conditions for survival of juvenile Greenland halibut transported to this area by warm Atlantic currents.

Thus, one should not exclude that persistent climate changes may lead to alteration of the marine ecosystems of the Barents Sea and adjacent waters and seas, as well as to changes in migration patterns and distribution areas of target species at different stages of their life span. Therefore, in the near future PINRO considers it important to continue expanding research in polar waters with the purpose of researching the new fishing grounds.

It should be remembered also that climate warming in the North Atlantic and Arctic and subsequent geographical re-distribution of living marine resources may give rise to political controversy between both states already enjoying their fishing rights to these resources, and potential claimants to a slice of the "fishing cake".

However, according to projections by PINRO, no dramatic changes in climate are expected in the North Atlantic until at least 2015. Therefore, it may be envisaged that the Barents Sea ecosystem on the whole will be functioning in the same way as now, and its fisheries potential will correspond to the current level. This means that at the present time, and in the foreseeable future, stock status of commercial fishes in the Barents Sea and adjacent waters will be determined by a management regime rather than by changes in the environment resulting from climate warming.

\section{Tackling climate change impacts on fisheries}

Keith Brander

DTU Aqua 
Charlottenlund, Denmark

\footnotetext{
“There is high confidence ... that observed changes in marine and freshwater biological systems are associated with rising water temperatures, as well as related changes in ice cover, salinity, oxygen levels and circulation”.

"Regional changes in the distribution and production of particular fish species are expected due to continued warming, with adverse effects projected for aquaculture and fisheries"

"Climate-related reductions in production cause fish stocks to decline at previously sustainable levels of fishing, therefore the effects of climate must be correctly attributed and taken into account in fisheries management”

"Reductions in the level of fishing are ... required in many cases to sustain yields and may also benefit fish stocks, which are sensitive to climate variability when their population age-structure and geographic sub-structure is reduced"
}

These statements, all from the 2007 IPCC report, point to issues which need to be tackled, but do not tell us how urgent they are. The urgency depends on how quickly the climate changes over the next 20-50 years, which is a question for climatologists. It also depends on the sensitivity of species and ecosystems, which is a question for biologists. However, for all heavily fished stocks it is much more urgent to reduce the level of fishing and this action will also offset the effects of climate change. Less fishing activity consumes less fuel, so a reduced level of fishing will reduce carbon emissions (mitigation) while maintaining catches as fish biomass increases.

\section{Reducing fishing mortality is a win-win strategy for overfishing and adaptation to climate change.}

Although we have high confidence that observed changes in marine and freshwater systems can be attributed to climate we have far less confidence in our predictions of future impacts. The basis for any biological prediction is the climate prediction and since biota respond to many factors in addition to temperature we need to ask climatologists to include these in their predictions (salinity, oxygen, $\mathrm{pH}$, wind, stratification, upwelling, mixed layer depth, nutrient supply, light). However, even if our climatological colleagues provide all of these, with estimates of their likelihood, it is extremely difficult to predict biological responses, even at the relatively trivial level of predicting changes in distribution. How can we increase our confidence in the predictions which we make?

Three kinds of evidence can be used in making predictions: 
- Use the past as an analog for the future. Previous warming periods (1925-1945; 3500 BC) show how quickly distributions and marine ecosystems changed in the past and which species existed.

- Investigate processes and include them in models to predict future changes. Examples include measuring the effects of low salinity (density) and oxygen on the viability of cod eggs and sperm; effects of high winter temperature on survival of oyster parasites.

- Carry out experiments in the field and in mesocosms. Predictions of future crop yields in the IPCC report and levels of confidence are mainly based on extensive experiments. Only a few experiments on effects of higher temperature (and other hydroclimatic variables) have been carried out for fish and the results are complex.

Future global fish production depends on how primary production changes, which has been modelled (Sarmiento et al. 2004). The authors have low confidence in the predictions, but show where improvements in our process knowledge are needed.

Climate has direct and indirect effects on the growth, maturation, survival, reproduction and distribution of fish, which affect their productivity and resilience. This means that they may no longer be able to sustain the same level of fishing and, therefore, management strategies based on biological reference points have to be adjusted. In some cases productivity will increase, so the level of fishing could be allowed to rise.

We need to:

- design monitoring strategies to detect critical changes in species and ecosystems

- implement responsive management which can adjust quickly

- identify species and ecosystems (e.g. Baltic cod) which are sensitive to changes in climate

- anticipate changes in distribution and prepare responses which avoid management conflicts.

Brander, K. M. 2007. Global Fish Production and Climate Change. Proceedings of the National Academy of Science, 104: 19709-19714.

Brander, K. M. 2007. Tackling Climate Change Impacts on EU Fisheries. El Anzuelo European Newsletter on Fisheries and the Environment, 19: 1

Easterling, W. E., Aggrawal, P. K., Batima, P., Brander, K. M., Erda, L., Howden, S. M., Kirilenko, A., Morton, J., Soussana, J.-F., Schmidhuber, J., and Tubiello, F. N. 2007. Food, fibre and forest products. In Climate Change 2007: Impacts, Adaptation and Vulnerability. Contribution of Working Group II to the Fourth Assessment Report of the Intergovernmental Panel on Climate Change. Edited by M.L.Parry, O.F.Canziani, J.P.Palutikof, P.J.van der Linden, and C.E.Hanson., Cambridge University Press, Cambridge,UK: 273-313. 


\title{
Aquatic organisms and diseases - an underlying threat when cold seas heat?
}

\author{
Stein Mortensen
}

Institute of Marine Research

PO Box 1870 Nordnes

5817 Bergen, Norway

Email: stein.mortensen@imr.no

Pathogenic and parasitic organisms represent a natural part of the marine ecosystem, and have co-evolved with their hosts. They play important roles and contribute to the dynamics of natural ecosystems. This dynamic balance is often difficult to measure and describe. Much of our present knowledge is, therefore, generated from aquaculture activities, where disease has been discovered, described and studied.

There will always be competition between species - always leading to changes, where environmental factors may influence the dynamics of the system. Temperature is an important factor, having a direct effect on biological mechanisms, determining the distribution, fitness and survival of marine species. Climate change may constitute slow, gradual change but may also cause acute and extreme situations, such as exceptionally warm summers, cold winters, unstable conditions, long lasting heavy rainfall etc. Although it is difficult to define the "abnormal", the pattern of climatr oscillations is important. Slow changes, such as a gradual, slow increase of water temperature, will give a gradual change in the marine ecosystem. As the environment changes, ecological niches occur and disappear. Populations of native species may increase or decrease. New species may represent new hosts, new carriers or new parasites. These processes are possible to follow and evaluate - if we have operative research and diagnostic services. Extreme conditions - like extreme temperatures, winds and changes in salinity - will have different effects. Extreme changes will challenge the limits of species - often causing dramatic changes in farmed fish and shellfish. Extreme temperatures may lead to physiological stress if animals cannot escape. Stress may lead to suppression of immune reactions, increasing the vulnerability to disease. Many pathogens will then get a "niche" in space and time - and affect a host population. Such "strikes" may cause mass mortalities in fish and shellfish populations.

All of these considerations are on a general and rather theoretical level - simply because the level of predictability is low. It lies in the nature of a pathogen to be both opportunistic and adaptive. History has shown us that we will be facing a series of numerous, previously unknown disease problems. Usually, we do not predict disease - even in species with a well known biology. We did not predict the severity of salmon louse infestations. We did not expect the viral diseases affecting salmon (e.g. Infec- 
tious Salmon Anaemia (ISA) or Pancreas Disease (PD)). Also, viral diseases which have caused serious problems in cold water marine fish farming (e.g. Viral Nerval Necrosis Virus) came as a surprise.

Through the last decades, we have, however, seen a series of diseases affecting marine aquaculture. The known cases can give us some degree of prediction, as the influence of environmental factors - like temperature - has been studied and described. We can make a long list of diseases expected to cause increased problems in warmer waters. Examples include both parasitic infestations with salmon lice, amoebic infections and a series of bacterial diseases such as Bacterial Kidney Disease (BKD), piscirickettsiosis, Aeromonas infections and francisellosis - the latter considered a serious threat to increased cod farming in Norway.

In conclusion, a number of diseases - known and unknown - represent an underlying threat when cold seas heat. From a management point of view, it is essential to identify the tools to counteract the emerging disease problems. Here too, we can learn from our recent history, and use knowledge and experience (which is simple, but not always the case):

- We must try to avoid spreading pathogens- do not "help” invading species to establish or transport them across natural barriers. Aquaculture causes a problem, as we frequently move juveniles over long distances. Will we repeat the mistakes made with salmon when we develop cod farming?

- We must improve legislation. A suitable model must enable us to "freeze" the situation when "new" diseases occur. Emerging diseases should always result in an immediate blocking of movements. Zoning should be used to prevent disease introduction, not only as a measure to prevent spreading of already present diseases. In order to rapidly counteract diseases, the legislation must include efficient contingency plans.

- We must define responsibility. Who is responsible for the health status of our wild fish and shellfish populations? Monitoring is expensive and time consuming and limiting the transport of live aquaculture animals is against the free trade models within the EU and any measure taken to increase the mortality rate due to disease in the stock management models will be met with protests.

More than ever, we are in need of good research, even better management, strong minds, solid integrity and strong necks.

\section{Aquaculture prospects in warmer coastal waters}

Øivind Bergh

Institute of Marine Research 
PO Box 1870 Nordnes

5817 Bergen, Norway

Email: oivind.bergh@imr.no

Global warming will gradually increase the temperature of Norwegian coastal waters and have significant effects on the aquaculture industry. In some places, fish farms will have to be relocated and farming technology modified in order to reduce the undesirable effects of higher temperatures. Unlike wild fish stocks, farmed organisms are quite literallly locked into specific localities. As a consequence, optimal farming conditions for the species common in Norwegian aquaculture today will gradually move northwards. Current sites will in turn be suitable for other species than those farmed today, and cultured species that are presently farmed in Southern Europe could gradually enjoy better conditions in Norway than further south. Examples of species that may be more important in the future are turbot, sea bass, sea bream, oysters and scallops.

Aquaculture is a fairly new industry in Norway, and in contrast to the fisheries, it lacks the historical reference to, and experience with, natural changes in climatic conditions. For instance, the cold winters along the Norwegian coast during the early part of the 20th century would have caused severe problems for the salmon farming technology of today. Furthermore, existing models point out that the expected changes are relatively slow in the context of industrial life-cycles. Although there is every reason to expect, and plan for, a gradual movement of the aquaculture industry northwards, there is no reason to quit salmon farming in southern Norway tomorrow.

Which changes are important? Studies of future climate show that air temperatures will rise by $2-4^{\circ} \mathrm{C}$ in the course of this century. In the seas off the coast of Norway, the temperature will raise by $1 \cdot 5-2.0^{\circ} \mathrm{C}$. This implies that the temperatures presently found in southern Norwegian coastal waters will be common along the coast of Northern Norway in a 50-100 year perspective. The change in the mean temperature is, however, not a major obstacle for farming of the presently most important species in southern Norway, Atlantic salmon, rainbow trout and Atlantic cod. In a biological context, extreme temperatures may be more important, especially considering the impact of high temperatures on the immune system and the proliferation of pathogenic agents. Periods with suboptimally high temperatures will be longer, and events with temperatures higher than the biological safe limits of the farmed species will be more common.

Other major effects of the expected climatic changes along the Norwegian coast during the next century will be increased intensity and frequency of storms and increased rain, plus a moderate increase of high tidel level. Although these effects will cause a need for improved technological solutions, and significant investments may be needed, they would 
not constitute "impossible" biological problems. Intense storms may, however, damage fish farms and increase the probability for "catastrophic "events with high numbers of escaped fish, unless improved technological solutions are developed and implemented.

Many diseases may occur more frequently in warmer weather, particularly bacterial infections with bacteria adapted to relatively high temperatures. For instance, francisellosis, vibriosis and furunculosis are typically associated with high water temperatures. On the other hand, winter ulcers and cold water vibriosis are typical examples of diseases that may be less frequent. Reproduction of salmon lice is temperature dependent, indicating shorter generation times, and increased infestation rates. However, spreading of salmon lice may be altered by increased freshwater along the coast, particularly in the fjords. Modelling of water movements in fjords and coastal environment in various climatic scenarios is a useful tool in order to predict changes.

\title{
Aquatic organisms and diseases - an underlying threat when cold seas heat?
}

\author{
Stein Mortensen \\ Institute of Marine Research \\ PO Box 1870 Nordnes \\ 5817 Bergen, Norway \\ Email: stein.mortensen@imr.no
}

Pathogenic and parasitic organisms represent a natural part of the marine ecosystem, and have co-evolved with their hosts. They play important roles and contribute to the dynamics of natural ecosystems. This dynamic balance is often difficult to measure and describe. Much of our present knowledge is, therefore, generated from aquaculture activities, where disease has been discovered, described and studied.

There will always be competition between species - always leading to changes, where environmental factors may influence the dynamics of the system. Temperature is an important factor, having a direct effect on biological mechanisms, determining the distribution, fitness and survival of marine species. Climate change may constitute slow, gradual change but may also cause acute and extreme situations, such as exceptionally warm summers, cold winters, unstable conditions, long lasting heavy rainfall etc. Although it is difficult to define the "abnormal", the pattern of climatr oscillations is important. Slow changes, such as a gradual, slow increase of water temperature, will give a gradual change in the marine ecosystem. As the environment changes, ecological niches occur and disappear. Populations of native species may increase or decrease. New species may represent new hosts, new carriers or new parasites. These 
processes are possible to follow and evaluate - if we have operative research and diagnostic services. Extreme conditions - like extreme temperatures, winds and changes in salinity - will have different effects. Extreme changes will challenge the limits of species - often causing dramatic changes in farmed fish and shellfish. Extreme temperatures may lead to physiological stress if animals cannot escape. Stress may lead to suppression of immune reactions, increasing the vulnerability to disease. Many pathogens will then get a "niche" in space and time - and affect a host population. Such "strikes" may cause mass mortalities in fish and shellfish populations.

All of these considerations are on a general and rather theoretical level - simply because the level of predictability is low. It lies in the nature of a pathogen to be both opportunistic and adaptive. History has shown us that we will be facing a series of numerous, previously unknown disease problems. Usually, we do not predict disease - even in species with a well known biology. We did not predict the severity of salmon louse infestations. We did not expect the viral diseases affecting salmon (e.g. Infectious Salmon Anaemia (ISA) or Pancreas Disease (PD)). Also, viral diseases which have caused serious problems in cold water marine fish farming (e.g. Viral Nerval Necrosis Virus) came as a surprise.

Through the last decades, we have, however, seen a series of diseases affecting marine aquaculture. The known cases can give us some degree of prediction, as the influence of environmental factors - like temperature - has been studied and described. We can make a long list of diseases expected to cause increased problems in warmer waters. Examples include both parasitic infestations with salmon lice, amoebic infections and a series of bacterial diseases such as Bacterial Kidney Disease (BKD), piscirickettsiosis, Aeromonas infections and francisellosis - the latter considered a serious threat to increased cod farming in Norway.

In conclusion, a number of diseases - known and unknown - represent an underlying threat when cold seas heat. From a management point of view, it is essential to identify the tools to counteract the emerging disease problems. Here too, we can learn from our recent history, and use knowledge and experience (which is simple, but not always the case):

- We must try to avoid spreading pathogens- do not "help" invading species to establish or transport them across natural barriers. Aquaculture causes a problem, as we frequently move juveniles over long distances. Will we repeat the mistakes made with salmon when we develop cod farming?

- We must improve legislation. A suitable model must enable us to "freeze" the situation when "new" diseases occur. Emerging diseases should always result in an immediate blocking of movements. Zoning should be used to prevent disease introduction, not only as a measure to prevent spreading of already present diseases. In order to rapidly 
counteract diseases, the legislation must include efficient contingency plans.

- We must define responsibility. Who is responsible for the health status of our wild fish and shellfish populations? Monitoring is expensive and time consuming and limiting the transport of live aquaculture animals is against the free trade models within the EU and any measure taken to increase the mortality rate due to disease in the stock management models will be met with protests.

More than ever, we are in need of good research, even better management, strong minds, solid integrity and strong necks. 


\section{Part 2. Implications of Climate Change.}

National - Transnational Implications. Convener: Alf Håkon Hoel, University of Tromsø

\section{An economic perspective on management implications of climate change}

Arne Eide

Norwegian College of Fishery Science

University of Tromsø

Tromsø, Norway

Email: arne@nfh.uit.no

Fishing is an economic activity based on available fish stock resources.

Biological resource properties and market characteristics determine the economic performance of the fishery. An ocean ecosystem is dynamic and the state of the system hard to measure and forecast. Previous fishing activity is one of several factors determining future stock situations. The core idea of introducing fisheries management is to control fishing activity to increase the probability of achieving desirable future stock development and to promote a sustainable fishery.

Open access to common-pool resources is known to involve severe market failures causing wasted resource rent and overcapacity in fishing. The management problem, therefore, essentially is to reduce the production of fishing effort. The choices of proper management means and level of fishing effort are however not trivial problems. Fish stock resources and fishing fleets are highly dynamic, non-transparent systems. Pulse fishing seems, for example, to be preferable on highly fluctuating stock biomasses, making higher fishing effort capacity advantageous.

The Barents Sea ecosystem is characterised by few dominating species with significant between and within year fluctuations. The fish stocks perform large annual migrations, adapting to seasonal changes while feeding and spawning. Fishers adapt correspondingly, targeting the fish during periods of high availability. Fleet diversity also reflects adaptation to fluctuating stock situations, benefiting different types of vessels at different times. Weather conditions and annual variations in temperature and fish abundance also influence fishing fleet strategies. Management 
constraints are, in this context, yet another factor the fisher has to adapt to.

The impacts of global warming on such systems are in principle of the same kind, as the probability space of natural fluctuations is altered and possibly extended, while the basic principles of adaptation remain; given that the changes induced by global warming do not significantly change the basic energy flows of the present ecosystem.

Several studies confirm management decisions to play a more significant role than possible impacts of global warming on the Barents Sea cod fishery. A fully integrated model study based on the B2 global circulation model by IPCC, suggests that stock fluctuations increase slightly as a consequence of a rather modest increase in average ocean temperature (in average $+0.5^{\circ} \mathrm{C}$ ) over the next 25 years. Monte Carlo simulations of stochastic inflow of young herring to the Barents Sea show varying economic performance of six different management regimes. Current management implementation of a precautionary approach by indicator based harvest control rules (HCR) performs less efficiently after climate change, while increased stock fluctuations benefit management strategies involving higher fishing pressure.

Another study, investigating different environmental situations, concludes that cod stock biomass increases slightly by a decrease in temperature of $2^{\circ} \mathrm{C}$. Still, management effects are found to be significantly more important than impacts of global warming.

Global warming may, however, affect more than ocean temperatures, growth rates and environmental saturation levels. Market effects may alter prices on input factors in fishing effort production and prices of fish products. Increased frequency of extreme weather events may increase cost of fishing and place constraints on fishing seasons. Increased awareness and focus on environmental issues may change the demand for fish products and, thereby, affect price setting. Effects may be positive or negative, depending on international and regional perceptions of ocean fisheries. Demographic changes and changes in the livelihoods along the North-Norwegian coast may also change fishing pattern and supply of fish from this region. The two studies referred to above do not include such considerations, as they base their conclusions on present cost and prices.

The importance of fisheries management is not diminished by global warming. Current HCR systems are, however, not sufficiently dynamic to cope with significant environmental fluctuations. HCR management could potentially be developed towards adaptive management tools. Developing adaptive, dynamic indicators utilised by proper HCRs may be the most adequate strategy of preparing for the consequences of global warming in fisheries. 
Eide, A. (2008). An integrated study of possible economic effects of global warming on the Barents Sea cod fisheries. Climatic Change, 87(1-2):251-262.

\section{Socioeconomic consequences of climate change in fisheries: a progress report of ongoing research.}

Grete K. Hovelsrud and Jennifer J. West

CICERO- Center for International Climate and Environmental Research Oslo, Norway

Email: g.k.hovelsrud@cicero.uio.no ; j.j.west@cicero.uio.no

In her opening speech at the Fisheries Management and Climate Change in the Northeast Atlantic and the Baltic Sea Conference, Helga Pedersen, Minister of Fisheries and Coastal Affairs, noted that both mitigation and adaptation to climate change are necessary, and need to be addressed by Nordic countries across all sectors of the economy, including within the fisheries sector. The research we discuss here, which is being undertaken in connection with a number of national and international projects at CICERO, focuses on adaptation to climate change as it relates to the fisheries sector, and coastal communities, in Northern Norway.

There is general agreement among social scientists that changes in climate will pose significant challenges for communities, particularly those in the Arctic, and in coastal regions. However, the nature of the risks, and the most effective means of dealing with them, are poorly understood. There are a number of challenges in studying the relationships between climate change, fisheries and people. Research considerations and challenges in our present work include:

1. Capturing the complexities and interlinkages between climate change, and changes in relevant social, economic and biophysical factors at different scales that are relevant for communities.

Social and ecological systems are not separate, but linked. On the one hand, warmer sea temperatures may lead to larger areas and improved growth conditions for certain commercially-important fish species in the Barents Sea, including cod and herring, and to new fish species, with potential economic opportunities for fishermen. On the other hand, weather patterns may become more unpredictable, potentially increasing hazards for fishermen at sea. Dealing with these changes may require a number of adaptations in the fisheries, such as shifts in fishing technology, better weather advisory services and information about where and what to fish, and new and flexible fishing regulations.

2. Direct and indirect effects of climate change on the Barents Sea fisheries. 
While climate change will impact fisheries in the Barents Sea directly through biophysical changes that affect fish stocks, a number of indirect effects of climate change on the fisheries are also expected. Increased oil and gas exploration and shipping activities, due to a reduction in sea ice extent in the Arctic Ocean, will result in more traffic at sea, leading to competition with fisheries over space, and questions of preparedness for coastal communities. There are presently no more than three weather buoys in the Barents Sea, and virtually no possibility of forecasting polar lows, for example. Ships will have to deal with an expected increase in storm surges, wave heights and wind, icing on equipment, increasing sea levels, and as a result, new environmental safety issues. The added risks to communities and the marine environment from major pollution resulting from offshore oil spills due to oil and gas activity is a cause for concern. An ice-free Arctic Ocean also raises international security questions, and discussions around fisheries regulations and access. How will these broader changes affect the vulnerability and adaptation of local communities who depend on fisheries in a changing climate? How will communities adapt to these combined challenges?

\section{Multiple factors affect adaptation.}

It is important to note that adaptation to climate change at the community level takes place in the context of multiple factors that are not necessarily related to climate change. Although climate change itself may not be an immediate concern for communities, this does not mean that it does not have an impact on peoples' well-being. Understanding how climate change affects people where they live and work requires investigating how and why people interact with their environments, what valued aspects of their livelihoods may be threatened directly or indirectly by climate variability and change, and the dynamic social, economic, cultural and institutional contexts that affect peoples' behaviour, priorities, perceptions and responses to changes that manifest locally. Socioeconomic barriers or opportunities for adaptation to climate change in the fisheries sector in Northern Norway include access to landing facilities and markets, fish prices, recruitment of young people to the fisheries, demographic trends (outmigration), increasing competition, overuse of the marine environment, changing fishing regulations and management frameworks, and the knowledge base of individual fishermen.

\section{Interdisciplinary research - an example of cooperation between social} and natural scientists.

Interviews and dialogue with fishermen in our case study sites shows that they are concerned about particular climate elements. These include: wind direction and strength (offshore winds provide different conditions 
than onshore winds); Polar lows (these are difficult to forecast, are localised, develop quickly and may occur with hurricane force winds); Storm surges and wave heights (raise safety at sea issues); Sea temperatures (affect distribution and behaviour of fish); and extreme events (combination of climate elements may lead to icing on vessels and equipment, inability to go out to sea, and destruction of fishing equipment). The challenge we face as researchers is that in many cases it is difficult to produce climate scenarios that can address the concerns of fishermen at a suitable scale and time horizon. But we are attempting to solve this in cooperation with our colleagues at the Norwegian Meteorological Institute. We also need information on the impacts of climate change on the marine ecosystem, and work with our partners at the Institute of Marine Research in Bergen, to benefit from their expertise in this area.

5. Linking information about local climate change impacts, vulnerability and adaptation to the appropriate decision-making structures at higher levels.

While we often think of climate change as a global issue, when it comes to human adaptation to the effects of climate change, action needs to take place locally. However, this does not mean that adaptation is disconnected from events, processes and decision-making structures at higher levels. Scaling up is important so that the findings not only have relevance for local communities, but also for decision-makers and policymakers. Designing and implementing effective adaptation policies for fisheries locally, nationally and internationally requires understanding how different fishing communities are affected by and respond to climate variability in the context of other ongoing societal changes. For example, the importance of fisheries, as measured by the share of employment, or gross value added of the sector, to municipalities in Norway, varies greatly. The impact of climate change on fisheries is, therefore, a greater concern for certain municipalities compared to other counties, or the nation as a whole.

\section{Conclusion}

We have shown, using examples from Northern Norway and the Barents Sea Region, that there are major complexities involved in understanding the socio-economic consequences of climate change on fisheries. The challenges relate to the adaptation research itself (choosing methods that capture an appropriate amount of complexity), and to the complexity of local adaptation actions, practices and contexts. Fundamentally interdisciplinary research, and integration of the scientific disciplines and users, are needed. Research that cuts across scales, using a comparative, place- 
based research approach, can help to link local realities with decisionmakers and structures at all levels. 


\title{
Part 3. Policy Implications
}

\author{
Convener: Mr. Robert Andrén, Ministry of Agriculture, Sweden
}

\section{Policy and management implications in fisheries of climate change}

\author{
Alf Håkon Hoel \\ Department of Political Science \\ University of Tromsø \\ Tromsø, Norway \\ Email: hoel@sv.uit.no
}

Climate change and its effects on the natural environment and humans is perhaps the major issue of our time. In relation to oceans and fisheries this concern has been voiced among others by the FAO Committee of Fisheries (COFI) in March 2007, the UN General Assembly in its 2007 fisheries and oceans resolutions, and by the EU Commission in its communication in March 2008 to the Council on Climate change and international security.

Climate change is now a topic for discussion in all economic sectors. A number of studies exploring the economic consequences of climate change and its security implications have been produced. In the fisheries sector, the study of policy implications of climate change is in its infancy - this is not an area where we can provide certain answers. We do know, however, that good management of fishereries is essential (ACIA 2005). By reducing fishing effort and fish mortality, stocks will become more resilient to change.

\section{Policy implications and the fisheries management toolbox}

A policy is an objective with the means to achieve it attached. Policies are developed and implemented by institutions, at various levels of governance ranging from the global to the domestic.

Policies are developed and executed in a particular context. In fisheres, the context is defined in the context of political and legal frameworks at the global, regional and national level. At the global level, the law of the sea convention and the UN Fish Stocks Agreement constitute the legal framework, supplemented by the FAO Code of Conduct for Responsible Fisheries. These provide the major principles for the man- 
agement of living marine resources. At the regional level, and pertaining to water beyond national jurisdiction in particular, Regional Fisheries Management Organisations (RFMOs) play an increasingly important role. The actual implementation of the rules and principles of this international framework occurs at the domestic level, usually by sector specific agencies administering sector specific legislation.

Traditional fisheries management basically has two sets of objectives: one relating to resource conservation and long-term sustainability, the other concerned with allocation of resources.

Good governance in fisheries is generally associated with the three policy elements: scientific knowledge, regulations of fishing activity, and enforcement of regulations. These are critical elements of management systems, and while their degree of sophistication varies, there is a trend over time during which these are improved upon.

Looking more closely at the regulatory element, the toolbox of managers, there are three sets of tools: restrictions on access to a fishery, limitations on quantities to be taken from any given stock, and restrictions on when, where and how to fish. These are complementary elements - their effects are dependent upon each other.

Environmental concerns are increasingly important in fisheries. Regulation- wise, this has manifested itself by the introduction of the precautionary approach and ecosystems-based approaches to management. The point of the precautionary approach is to be explicit about and take account of risk. The issue in ecosystem based management is to take account of the interaction between the environment and fisheries and to reconcile the various concerns that arise in an integrated manner.

\section{Policy implications of climate change and fisheries}

In a general perspective, there are two sets of policy issues that climate change raisea for fisheries. One is the need to reduce emissions of gases that contribute to global warming, notably $\mathrm{CO} 2$ - mitigation. The other is the need to adapt to a changing environment - adaptation.

The current global climate regime, as laid down in the Kyoto Protocol, requires developed countries to cut their emissions to an average of $5.2 \%$ of 1990 levels by 2008-12. In a longer time perspective (2050), emissions have to be reduced to at least $50 \%$ of 1990 levels in order to limit global temperature increases to levels commensurate with the current state of the natural environment.

The protocol provides emission targets for developed countries and a clean development mechanism (CDM) whereby developed countries can buy emissions credits in developing countries: by paying others not to pollute, you get credited in you own climate account. An important aspect is that emissions quotas can be traded. The point is to cut emissions with as low costs as possible. 


\section{Mitigation}

Mitigation is about reduction of emissions from fisheries. Globally, shipping contributes $2-3 \%$ of emissions. The role of fisheries in that picture is very small $-1-2 \%$, but nevertheless significant. While the fishing industry today may not be subject to $\mathrm{CO} 2$ levvies, it is unrealistic that any industry in the future can escape this. In some instances fuel is also subsidized, and this practice is inconsistent with the need to reduce emissions.

Among the potential measures are $\mathrm{CO} 2$ taxes, requirements to fish in more energy-friendly ways, purchase of $\mathrm{CO} 2$ quotas, and so on. It should be noted that capacity reduction in the fishing fleet may generally contribute to reduced emissions. In the perspective of resource management, this is therefore a win-win situation, where a reduction in capacity may reduce effort, which is beneficial for conservation of resources, and reduce emissions of climate gases.

An important concern in this regard is the need for a level playing field. If the industry in one country has to pay $\mathrm{CO} 2$ taxes and those in another country not, the latter will have a competitive advantage.

\section{Adaptation}

First of all, the fshing industry is in the business of adapting to change in the natural environment. Adapting to fluctuations in resources and changes in geographical range is an area of expertise in the industry and its managers. So, in this case the question is how the management toolbox can be put to best use. The consensus among the scientists who have studied the issue is that good management is still the essential question (ACIA 2005, Eide 2007). Climate change does not demand a wholesale retooling of management, but rather more of the same in terms of current best practices.

One issue in this regard is that climate change brings increased uncertainty. According to the precautionary approach, we therefore have to reduce risk, which translates into larger margins of safety and smaller quotas. Another issue is the need to integrate our knowledge about climate change into the knowledge base for management.

A frequently encountered argument in discussions about climate change and fisheries is that fish have always moved and that changes in migratory ranges is nothing new. This is of course correct. But what is new - in an historical perspective - is the emergence since the 1970s of boundaries in the oceans defining who owns what and who can decide what where. The law of the sea establishes that coastal states can have 200 mile Exclusive Economic Zones (EEZs) where they have sovereign rights over natural resources. While a fishing vessel forty years ago could follow the fish, it cannot do so today if the fish enter the waters of another country. In an historical perspective this is an entirely new situation where the effects of climate change raises a host of new issues. 
Complicating this is the fact that fish stocks often straddle boundaries and occur in the waters of more than one state and in addition also international waters beyond national jurisdiction. Also in such cases ocean law provides some guidance. The principles for distributing resources on several "owners" in the case of transboundary resources are basically zonal attachment and traditional fishing. That is, a state may have an ownership share in a fish stock that corresponds to the share of the stock occurring in its waters, and/or a share corresponding to its historical share of the catch. This is not rocket science, and in practice also bargaining power plays a role in determining outcomes.

Particularly difficult are the cases where a fish stock is found also in international waters. In such instances RFMOs and similar arrangements play a critical role in ensuring that management measures are adopted also for the high seas.

Over the last two decades we have seen a number of fish stocks changing their migratory range considerably, to enter other EEZs and/or international waters. This applies for example to Norwegian spring spawning herring as well as to mackerel. Both cases shows that although it is difficult and takes hard bargaining and political will, such situations can be handled. One option is to negotiate a new regime and sharing arrangement based on new migratory ranges (e.g. herring). Another is to stick to the existing regime for as long as it remains relevant (e.g. mackerel).

This all depends on the level of change, however. If major changes occur over short time spans, it is more difficult to handle than a situation with minor changes over longer time. Still, another factor in the equation is the stock situation: it is easier to reach agreement on allocation when stocks are growing than in the face of stock reductions.

\title{
EU fisheries, climate change and management implications
}

\author{
Poul Degnbol \\ Scientific Adviser \\ European Commission, DG Fisheries \& Maritime Affairs \\ Email:poul.degnbol@ec.europa.eu
}

Climate change and fisheries interact both ways: industrialised fisheries contribute to climate change through emission of greenhouse gasses. The fisheries sector must, therefore, take its share of contributing to mitigation. Fisheries are affected by climate change because the resource bases for fisheries, the marine ecosystems, change. The fisheries sector and public policy must, therefore, adapt to climate change. 
Fisheries impacts on climate by being responsible for $1.2 \%$ of global oil consumption.

The consumption of oil is very variable, dependent on the fishery. The global average is $0.45 \mathrm{~kg}$ fuel per $\mathrm{kg}$ fish landed (640 l/ton). European fisheries do, however, amongst its many diverse fisheries, have some of the most oil consuming fisheries globally - it can be $4 \mathrm{~kg}$ fuel per $\mathrm{kg}$ fish landed in beam trawler fisheries. There have been low incentives for the industry to develop energy efficiency. On the contrary, the tax exemption for oil to fisheries can be considered a subsidy to the sector which has had the opposite effect of being a counterincentive for energy efficiency. However, more recently the high fuel prices have created a strong incentive for change.

Mitigation in this sector is primarily promoted through the general mitigation policy of the Community. Beyond this, energy saving technologies and practices are promoted by the Commission. There is considerable potential for reducing the emissions relative to landings. The policies we pursue for conservation reasons and to improve the economic performance of the fleet such as a reduction in fleet capacity together with healthier stocks will be the most important contribution to improved energy efficiency because a smaller fleet will harvest from larger fish stocks. The Commission is also facilitating information exchange on energy efficiency through a study and a web site with information available to operators in the sector.

The impacts of climate change on fisheries are expected to be very considerable and complex. The major features of relevance to fisheries management are not only northward changes in distribution but also changes in ecosystem productivity and that sustainable fisheries may need to exert lower fishing pressure when climate change is an added stress on fish populations and ecosystems. What is also new, with regard to earlier changes in the marine environment, is that the change predicted due to climate change is more rapid than earlier changes within the most recent several thousand years.

It is a challenge to both industries and public policy to adapt to this.

From an industry perspective, more rapid changes in the resource base and cautious management, means that the industry needs to develop its flexibility even further in order to adapt to new conditions. The need for flexibility and a changing resource base may, on the other hand, discourage long term investment. We are trying to promote incentives for a longer investment horizon to encourage the industry to take a longer term responsibility so this may counteract these attempts. The industry may be facing new mechanisms to distribute access as the geographical distribution of stocks change. Existing access rights may change considerably in 
value as the volume (and thus value) of a stock changes as a result of climate change.

The adaptation of public policy is threefold: 1) maintain (or rebuild) resilience of marine ecosystems and fish stocks, 2) ensure that adequate measures will be taken as changes appear by developing a responsive and responsible decision framework and 3) Prepare response to distribution issues as fish stocks change distribution or new fishing opportunities appear.

1. Maintaining (or rebuilding) resilience of marine ecosystems and fisheries. This means that we should do effectively what we try to do anyway - to reduce the fishing pressure and fisheries impacts on ecosystem. Climate change is an added stress on marine ecosystems and fish stocks on top of fisheries, pollution etc. Climate change, therefore, makes the need to reduce fishing pressure even more urgent.

The first priority is, therefore, to do effectively what we try to do already to move to sustainable fisheries - to reduce overall fishing pressure and reduce capacity

2. Ensure that adequate measures will be taken as changes appear by developing a responsive and responsible decision framework. Climate change has highlighted that we have been operating within a false mindset of nature being constant - climate change and considerations of ecosystem linkages require management to be adaptive in a changing environment. Proper monitoring and scientific analysis needs to be in place which enables early warnings of changes and also of regime shifts. However, warnings about regime shifts are very difficult to get because science does not have good methods to identify such shifts in the early stages. Management plans must be made such that they are adaptive. This is what we already are trying to do with most recent plans. The discussion paper for the next cod recovery plan does specifically mention the changing environment as a reason to propose a new approach. We need to develop a responsible and responsive decision process which does not lead to complacency in times of little change and can react rapidly when required.

3. Prepare response to distribution issues as fish stocks change distribution or new fishing opportunities appear. Questions of distributions of access will be raised in international fora as the geographical distribution of stocks change. We need to discuss and get decision rules for this early on, preferably before the changes in the sea have taken place. We think that generally, access is based on historical precedence of catches rather than geography. Another case is 'new' stocks, when fish species occur in areas where they did not 
occur before. This creates the risk of the development of unregulated fisheries and early measures need to be taken to manage emerging fisheries - it is difficult to reverse overfishing. We must establish mechanisms which introduce regulation (and distribution of access) in such cases.

\section{Challenges for the fishing industry}

\section{Jan Ivar Maråk}

The Norwegian Fishing Vessel Owners Association

A lot of the rhetoric and media coverage on climate changes is unfortunately based on scare stories aimed at raising awareness. There is little doubt that many of the climate changes we see are natural changes that can be scientifically explained. At the same time there is high probability that parts of the climate changes are results of human behaviour, and this is important to take seriously. We have to act in a precautionary manner.

The conference sets its main focus on how fisheries management can meet the challenges of climate change. This is important, as it is also important to discuss how the fisheries industry should take its part of the responsibilities to reduce emissions causing climate change. It is our ambition that the Norwegian fishing industry shall play an active role in this process, and we believe it is possible to do so without reducing the overall level of production.

Recruitment and survival of important fish stocks usually improves in periods of warmer water temperatures. We also know that growth rates of fish increase with warmer water. Changes to the productivity of fish stocks are, therefore, probably the area of least concern in relation to climate changes, at least if the scenario is a limited temperature rise.

We have seen that the distribution pattern of many species changes with sea temperature changes.

A central principle in Norwegian fisheries negotiations has been to advocate the zonal attachment principle, and this is likely to remain so in future. If fish stocks over time change their area distribution, this may give reason to raise new stock sharing discussions between countries.

Climate- or $\mathrm{CO} 2$ accounting can provide valuable information about which products represent the largest emissions, and how we might as consumers contribute by changing our eating habits. However, it is necessary to treat such climate accounts with caution. Comparisons and calculations are very complex, and results differ from one analysis to another.

Studies indicate that new technology on vessel and equipment can give as much as $30-40 \%$ fuel reductions. To realize much of the potentials in the fishing fleet it is necessary to increase earnings and profitabil- 
ity and secure vessel renewals. It is also necessary to go through a variety of regulatory measures again, where energy efficiency is given more weight than has been the case so far. The end goal must be to improve energy efficiency of the fishing fleet within the boundaries of a sustainable fisheries management. The fishing industry is probably the most politicised industry in Norway. We believe it will be difficult for the government to continue this policy in a situation where more attention is drawn to climate changes.

The environmental organisations have an important an actually fairly simple task with respect to climate change. The climate threat has provided the environment NGOs with a significantly improved platform for taking part in the public debate. Fortunately most organisations contribute to the debate with factual and considered opinions. Some NGOs are, unfortunately, using the increased attention to continue and increase their campaigns against the fishing fleet. There is good reason to fear that some green NGOs will use, or abuse rather, their increased power and influence to work for a more conservationist fisheries management policy.

In brief, the climate changes have reached a point where it is necessary for politicians to make some hard decisions. They have to decide, is the climate issue the greatest challenge to man in recent times? If so, this must also influence fisheries policies, and probably in a major way. At its most extreme we could probably fish all Norwegian quotas with 100 vessels or so. We are currently using about 2000. I am not saying that we should go to these extremes, but the direction is obvious for anyone willing to see. At the very least, we have to look again at the many individual fisheries regulations within our current fisheries management, with a view of analysing whether the benefits they provide outweigh the climate cost they cause. I am confident that it is possible to reduce climate gas emissions from the fishing sector significantly, without reducing productivity and output from the industry. Food from the oceans has a golden opportunity to enhance its position as healthy and environmentally friendly food, and the fishing industry and fisheries management should take advantage of this opportunity through close cooperation and a willingness to think along different lines from the past.

\title{
Climate change from an indigenous people perspective
}

\author{
Professor Svein Dish Mathiesen \\ Nordic Sámi Institute, Norway
}

No abstract at 20 June 2008 
Climate change effects on aquaculture and adaptation measures for a growing sector

Doris Soto1

Aquaculture Management and Conservation Service (FIMA) Fisheries and Aquaculture Department, FAO of the United Nations Email: doris.soto@fao.org

Aquaculture continues to grow more rapidly than all other animal foodproducing sectors. Worldwide, the sector has grown at an average rate of 8.9 percent per year since 1970, compared with only 1.2 percent for capture fisheries and 2.8 percent for terrestrial farmed meat-production systems over the same period (SOFIA $2006^{2}$ ). Aquaculture now accounts for nearly half (45 percent) of the world's food fish ${ }^{3}$ and this increase is expected to reach 50 percent by 2015. Although production remains predominantly Asian and still largely based on small-scale operations, there is a wide consensus among many that aquaculture has the potential to meet the growing global demand for nutritious food fish and to contribute to the growth of national economies, while supporting sustainable livelihoods in many communities.

Another relevant element to understandclimate change (CC) potential impacts on aquaculture is the present geographical distribution of the sector's production. By 2006, considering a global production of 66 million tonnes and a value of 86 billion US\$, 92\% of global aquaculture production is concentrated in Asia (mainly China) and $45 \%$ of global production comes from freshwater also from Asia, while also a large proportion of the estimated value is concentrated in Asia (79\%). It is clear that any CC associated effects on the sector in this region will have indirect effects on the global aquaculture outcome.

Some climatic changes may affect aquaculture in a positive way for example increasing productivity, also it is difficult to discern the causal effect of different elements of impacts of CC on aquaculture and separating these from other human stressors. Those elements of CC that are likely to impact on aquaculture, based on the IPCC forecast (2007), can be summarized as follows: i) global warming with increasing water temperatures likely to affect more poikilotherm aquatic organisms (most aquaculture species). Such increase will likely have relevant consequences, for example diseases and pests can be exacerbated in warmer waters if only because causing stress to fish; ii) rise in sea level, a likely

\footnotetext{
${ }^{1}$ The information presented here is a summary of a review paper by De Silva, S. and Soto, D. "Climate change and aquaculture" (in prep) and from the information collated and discussed by a FAO Fisheries and Aquaculture Department experts meeting on Climate Change implications for Fisheries and Aquaculture held in Rome April 7-9 2008.

${ }^{2}$ http://www.fao.org/docrep/009/A0699e/A0699e00.htm

3 "Food fish" or simply "fish" in this document refers to production of aquatic animals (fish, crustaceans, molluscs, echinoderms, amphibians). Aquatic plants are considered separately.
} 
consequence of global warming, will profoundly influence deltaic regions, increase saline water intrusion bringing about major biotic changes. These will affect negatively some types of aquaculture but may enhance mariculture; iii) major changes in ocean productivity and circulation patterns are predicted and pelagic fisheries could be more sensitive and, therefore, the availability of fishmeal/oil for aquaculture could be affected; iv) occurrence of extreme climatic events and increasing storminess in general will affect infrastructure and potential increase in escapees; v) water stress in many regions which will affect not only water for aquaculture but also for feeds of terrestrial origin; vi) increasing interest for biofuels is already increasing competition for some grains and sources of feeds for aquaculture (e.g. corn) already producing increases in feed prices.

Considering the above potential impacts, comprehensive adaptive measures can be divided into: i) "institutional measures" (including polices, planning and strategies) and ii) technological and practical (hands on) measures. Within the institutional component it is important to mention a) the need for implementing an Ecosystem Approach to Aquaculture (EAA) as a global strategy and b) the need for strengthening/enhancing mariculture and particularly non-fed aquaculture (filter feeders, macroalgae) as priority areas for development of the sector.

The EAA is a strategic approach to development and management of the sector aiming to integrate aquaculture within the wider ecosystem such that it promotes sustainability of interlinked social-ecological systems (SOFIA 2006, Soto et al. in press). Aquaculture cannot adapt on its own, more than ever there is a need for a cross sectoral view together with agriculture, forestry, fisheries, and urban development. The watershed, lake, coastal zone, fjord must be managed in a coherent way under CC scenarios. The watershed aquaculture scale approach is needed for an organized -cluster-type adaptation, e.g. collective insurance, biosecurity. On the other hand aquaculture can provide an adaptation for other coastal and inland sectors particularly when considering sea level rise affecting coastal agriculture and farming.

Technical adaptations include: i) more than ever better management practices (BMPs) at the farm level, can be the best adaptation approach including comprehensive risk assessments of sites, using appropriate technologies, adequate species, improving feeding and stress management; ii) changing, modifying feeds to rely less on fish meal and fish oils and particularly considering by products from other sectors; iii) exploring new species, new technologies, biotechnology and genetic improvement for better adaptation to new and or changing environmental conditions; iv)lLearning from experience of the expansion of farming species outside their original range. For example, there is plenty of experience on bringing salmon aquaculture abroad from its origins, facing different climates, weather conditions and vulnerability to old and new diseases. Therefore, 
a great deal of the "adaptation knowledge" may be already within the aquaculture industry and amongst pioneer farmers and perhaps it is time to collect such information globally; v) diversification of aquaculture. As in evolutionary terms it is commonly understood that diversity provides the basis for natural selection and for adaptation, therefore, it can also be proposed that culturing more species can provide a sort of insurance and better adaptation possibilities under different CC scenarios, especially in the face of unexpected events such as disease outbreaks. However, diversification clearly requires educating consumers and providing them with adequate information about new species and products. Considering the relevant water body scale two measures must be considered: vi) biosecurity must be in place to avoid and minimize the risk of diseases and expansion of aquatic pests and exotic species; vii) integrated monitoring systems to provide adequate information on physical and chemical conditions of aquatic environments, early detection of diseases and presence of pest species including harmful algal blooms. This must be accompanied by risk communication strategies and early warning systems to prepare and warn stakeholders. Other relevant measure is viii) focus on improving energy and water efficiency uses in aquaculture. 



\title{
Summing up remarks.
}

Knowledge Gaps and the next steps to be taken.

\author{
Concluding remarks by
}

Poul Degnbol

Scientific Adviser

European Commission, DG Fisheries \& Maritime Affairs

Email:poul.degnbol@ec.europa.eu

Poul Degnbol from the European Commission expressed appreciation that this forum had truly served to communicate complex scientific issues regarding climate change impacts to policy makers and other stakeholders and that the Conference had taken the first steps to understand the policy implications. We need now to work further to develop the policy answer and to implement it. The European Commission is working on a general adaptation strategy which also will include fisheries issues and results from this Conference will be taken onboard. We also look forward to further cooperation with Nordic countries on this matter.

\section{Concluding remarks by}

Tryggvi Felixson

Head of Department

Nordic Council of Ministers (NCM)

I would like to start by referring to a Conference in Stockholm earlier in the week on "resilience". In the summing up for policy makers I find a number of points relevant for the Bergen conference, including:

- The eco-system is the fundament for human society.

- Last 10.000 years the Planet and its eco-systems have been in a favourable state for human development. Now the Planet could be on the way to an undesirable state.

- Capacity to reduce shocks has been reduced through the destruction of ecosystems and reduced biodiversity. We cannot negotiate with the biosphere.

- Science has limited knowledge and uncertainty will always be there. Consequently, a precautionary approach is very important for promoting resilience. 
- Resilience is the key to human wellbeing; and biological, economic and social diversity is the fundament for resilience.

This conference has confirmed that there is a high degree of uncertainty about the consequences of climate change for Nordic oceans:

- First of all we do not know the outcome of the negotiation for a post Kyoto agreement. The outcome may be helpful in understanding what will be the course of human emissions of greenhouse gases (GHG) in the future. Thereby, we will be in a better position to know what IPPC scenarios are most likely to occur.

- Secondly, we do not know how the climate reacts to greater concentration of GHGs in the atmosphere.

- Thirdly, in the North Atlantic a change in ocean currents may have larger impact than rising average global temperature.

- Fourth, acidification of the oceans may counterbalance possible rise in productivity that higher temperatures can induce.

As a point of departure, the call of the Nordic prime ministers for a Nordic leadership in dealing with the global challenge of climate change should be noted.

So, where can the NCM serve as a useful instrument for the Nordic countries, in addition to supporting the effort to reach a global agreement on GHGs emissions in Copenhagen in 2009? The following issues are highly relevant for the work of the NCM in the years to come.

The research challenge is immense and truly transboundary, and can only be met through extensive international cooperation. Global climate models should be further developed, particularly when it comes to the importance of the large current systems. There is also a need to develop regional models for areas such as the Arctic, the North East Atlantic and the Baltic Sea. More detailed regional models are a prerequisite for risk assessment, better policymaking and fisheries management in the future.

A change in the distribution of fish species and other marine organisms is a likely outcome of expected climate changes. Policy makers in the Nordic countries should be prepared to adjust the distribution of quotas between their countries accordingly. Fisheries management schemes, that can quickly be adapted to new information about the state of the ecosystem, need to be developed.

The fisheries sector should also become more active in abatement efforts in order to develop technology and methods for reducing emissions of GHGs.

NCM is supporting several Nordic initiatives related to climate change and its effects on the ocean. Some of these initiatives are about reducing GHG from the fishing fleet, while others deal with the importance of ocean current systema and likely distribution of the major commercial 
fish species. The NCM (the ministers for fisheries, agriculture, forestry and food) will hold their annual meeting in Sweden in the summer. At the meeting it will be possible to put forward some of the main findings from this conference.

Strong stocks of fish are more resilient to climate change and other stressors than weaker populations. This fact, well stressed during this Conference, needs to be recognised. There are additional benefits from maintaining strong fish stocks. Stronger fish stocks will lead to more catch per unit of fishing effort and therefore it be expected that fisheries will become more economical and $\mathrm{CO} 2$ emission from fishing will be reduced.

Finally, the NCM should explore the possibilities to develop its cooperation with the EU on research and policy issues related to climate change. Common efforts should focus on marine issues in the Arctic and EU's North-eastern corner since this is probably where the EU and the Nordic countries have much in common and where there are a lot of synergies to be gained from closer cooperation between the two.

\section{Concluding remarks by}

Secretary General Mr. Jørn Krog

Ministry of Fisheries and Coastal Affairs

Oslo, Norway

It was important to arrange this Conference on climate change to identify the need for knowledge and the views and suggestions concerning how to cope with some of the coming challenges.

The questions that need to be answered are: What must we prepare for and what can be done?

It is difficult to sum up impressions from this Conference. There have been many interesting subjects. Most presentations were, however, from the Nordic countries and Norway. I was missing more contributions from the EU and the southern part of the North Atlantic.

We have discussed many important issues, but maybe the most important issue in years to come was not discussed during this Conference - the impact of human beings:

- The growth in the human population

- The increased in need for food

- The increase in demand and use of fossil fuels.

What extra dimensions are added? How can we deal with this problem?

The history of marine resource management started at the end of the last long decadal low temperature period and has, therefore, developed during a period of increased warming of our sea areas. Constant historical fluc- 
tuations in temperature have demonstrated that we and our ecosystem, until now, have been able to adapt to changes.

However, there are several new parameters we have not experienced before. The unexpected increase in temperature the last decade, the evident influence observed in the Arctic and the decrease in sea ice in the area give rise to concern.

The crucial questions are:

- For how long will we stay within historical norms?

- Will we experience shifts - "tipping points" - beyond our knowledge?

- How to cope with changes when we lack historical reference points?

To deal with this problem we must use and extend the need for a precautionary approach to protect the environment from depletion of living recourses and the increase in greenhouse gases.

\section{How can the industry contribute to cut emissions?}

There is one arena for competition and there is another arena for cooperation. To operate in the same arena for competition we need to develop common global regulations, taxes and subsidies on emissions.

In the arena of cooperation we must develop a comprehensive economic policy in the North Atlantic states to develop common goals and design common policy instruments. We must emphasize regional cooperation and find a system for best practice. This will be crucial in order to reduce emissions.

It is also needed regional and global scientific cooperation through common agreements; research programmes and a management system than can handle the coming changes.

ICES is a vital part of our management system. The question is if this system is adequate for the coming management challenges. I think so. But - there must be a closer cooperation between the national management system, the industry and ICES. This will make us better.

This must be discussed in the months to come in negotiations with the Nordic countries, the EU and the Russians.

Finally, what are the needs for knowledge? To identify the coming changes we must intensify monitoring of the oceans. Not only the living resources. The need for oceanographic data is also crucial - nationally, regionally and globally.

Politics should respond to knowledge and thereby define the needs for new knowledge.

The purpose of this Conference was to identify challenges. My reflections these days have been: "Interesting presentations that need to be used in our everyday thinking”. 


\section{APPENDICES}

\section{Appendix I: Conference Agenda}

Wednesday 16 April 2008

1800 Informal reception at the Institute of Marine Research (a 15 min walk from the hotel), Nordnesgaten 50, Bergen

Thursday 17 April 2008 (at the conference hotel)

$0900 \quad$ Welcome

Director Tore Nepstad, Institute of Marine Research

Ms. Lisbeth Iversen, Deputy chair of the City Government of Bergen

Opening address

Mrs. Helga Pedersen, Minister of Fisheries and Coastal Affairs, Ministry of Fisheries and Coastal Affairs, Oslo, Norway

Secretary General Mr. Halldór Ásgrimsson, Nordic Council of Ministers

Part 1 Changes in Climate, Fish Stocks and Aquaculture Changes in Ocean Climate

(Convener: Ole Arve Misund, Institute of Marine Research, Norway)

1000 The IPCC forecasts of climate change, Dr. Inger HanssenBauer, The Norwegian Meteorological Institute, Oslo, Norway.

1030 Ocean climate variations and predictions in the Northeast Atlantic Ocean. Dr. Bogi Hansen, Faroese Fisheries Laboratory, Torshavn, Faroese Islands

$1100 \quad$ Coffee break

Fish Stocks and Climate 
(Convener: Fredrik Arrhenius, Swedish Board of Fisheries, Gothenburg, Sweden)

1130 Predictions of changing fish stock production, distribution and migrations in the Northeast Atlantic. Dr. Randi Ingvaldsen, Institute of Marine Research, Norway

1200 Possible ecosystem changes when climate change in the Baltic. Professor Brian MacKenzie, National Institute of Aquatic Resources, Denmark

1230 Climate change impacts on marine ecosystems and fish populations in the North Sea and west of the British Isles. Professor Svein Sundby, Institute of Marine Research, Norway

$1300 \quad$ Lunch

Part 2 Implications of Climate Change

Capture Fisheries and Aquaculture Implications

(Convener: Poul Dengbol, EU Commission, Belgium)

1400 “In Dead Water”. Dr. Peter Prokosch, UNEP/Grid- Arendal

1430 Climate change in fisheries in the North Sea and west of the British Isles. Dr. Bill Turell, Marine Laboratory, Aberdeen, UK

1500 Will the Polar waters become the new fishing grounds? Dr. Konstantin T. Drevetnyak, PINRO, Murmansk, Russia

1530 Tackling climate change impacts on fisheries. Dr. Keith Brander, GLOBEC, Copenhagen

$1600 \quad$ Coffee break

1630 Aquatic organisms and diseases - an underlying threat when cold seas heat? Dr. Stein Mortensen, Institute of Marine Research, Norway

1700 Aquaculture prospects in warmer, coastal waters. Dr. Øivind Bergh, Institute of Marine Research, Norway

National - Transnational Implications

(Convener: Alf Håkon Hoel, University of Tromsø)

1730 An economic perspective on management implications of climate change. Dr. Arne Eide, Norwegian College of Fishery Science, University of Tromsø, Norway

1800 Socioeconomic consequences of climate change in fisheries. Dr. Grethe Hovelsrud, CICERO, Oslo, Norway 
Friday 18 April 2008

Part 3 Policy Implications

(Convener: Mr. Robert Andrén, Ministry of Agriculture, Sweden)

$0900 \quad$ Policy and management implications of climate change. Dr. Alf Håkon Hoel, University of Tromsø, Norway

0930 EU fisheries, climate change and management implications. Dr. Poul Degnbol, Scientific Adviser, EU DG Fish, Brussels

1000 Challenges for the fishing industry. Mr. Jan Ivar Maråk, The Norwegian Fishing Vessel Owners Association, Norway

$1030 \quad$ Coffee break

1100 Climate change from an indigenous people perspective. Professor Svein Dish Mathiesen, Nordic Sámi Institute, Norway

1130 Adaptations of the aquaculture industry to climate change. Ms. Doris Soto, Senior Fishery Resources Officer, FAO

1200 Summing up remarks (The next steps to be taken, knowledge gaps)

Director-General Dr. Fokion Fotiadis, EU DG Fish, Brussels, Belgium

Tryggvi Felixson, Nordic Council of Ministers, Copenhagen, Denmark

Secretary General Mr. Jørn Krog, Ministry of Fisheries and Coastal Affairs, Oslo, Norway 


\section{Appendix II: List of participants}

\begin{tabular}{|c|c|c|}
\hline Name & Organization & Country \\
\hline Søren Abrahamsen & EnviroBaltic & Danmark \\
\hline Katarina Abrahamsson & University of Gothenburg, Sven Lovén Centre of Marine Sciences & Sweden \\
\hline Dag L Aksnes & University of Bergen, Deptartment of Biology & Norway \\
\hline Hans Inge Algrøy & Norwegian Seafood Federation & Norway \\
\hline Johanna Andéasson & Swedish Board of Fisheries & Sweden \\
\hline Guro Andersen & Directorate for Civil Protection and Emergency Planning & Norway \\
\hline Robert Andrén & Ministry of Agriculture & Sweden \\
\hline Johanna Andreasson & Swedish Board of Fisheries & Sweden \\
\hline Yngvild Herje Arnesen & Office of the Auditor General of Norway & Norge \\
\hline Fredrik Arrhenius & Swedish Board of Fisheries & Sweden \\
\hline Halldór Ásgrímsson & Nordic Council of Ministers & Denmark \\
\hline Ingunn E. Bakketeig & Institute of Marine Research & Norway \\
\hline Øivind Bergh & Institute of Marine Research & Norway \\
\hline Howard Browman & Institute of Marine Research & Norway \\
\hline Ingela Byfors & Ministry of Agriculture & Sweden \\
\hline Marius Dalen & Bellona & Norway \\
\hline Poul Degnbol & $\begin{array}{l}\text { European Commission, Directorate General for Fisheries and } \\
\text { Maritime Affairs }\end{array}$ & Belgium \\
\hline Are Dommasnes & Institute of Marine Research & Norway \\
\hline Konstantin Drevetnyak & Polar Institute & Russia \\
\hline Patrik Edman & Nordic Council of Ministers & Denmark \\
\hline Arne Eide & Norwegian College of Fishery Science, University of Tromsø & Norway \\
\hline Aksel Reidar Eikemo & Directorate of Fisheries & Norway \\
\hline Sigmund Engesæter & Directorate of Fisheries & Norway \\
\hline Ylva Engwall & Swedish Board of Fisheries & Sweden \\
\hline Maren Esmark & WWF-Norway & Norway \\
\hline Tryggvi Felixson & Nordic Council of Ministers & Denmark \\
\hline Name & Organization & Country \\
\hline$\varnothing y v i n d$ Fiksen & University of Bergen & Norway \\
\hline Lothar Fischer & German Fishermens Association & Germany \\
\hline Petter Fossum & European Commission & Belgium \\
\hline Lidvard Grønnevet & World Bank & USA \\
\hline Ásmundur Guðjónsson & Nordic Council of Ministers & Denmark \\
\hline Jacob Hagberg & Swedish Environmental Protection Agency & Sweden \\
\hline Olle Hagstrom & European Commission & Belgium \\
\hline Elen Hals & Institute of Marine Research & Norway \\
\hline
\end{tabular}




\begin{tabular}{|c|c|c|}
\hline Name & Organization & Country \\
\hline Bogi Hansen & Faroese Fisheries Laboratory & Faroe Islands \\
\hline Inger Hanssen-Bauer & The Norwegian Meteorological Institute & Norway \\
\hline Nina Hedlund & Research Council of Norway & Norway \\
\hline Mikko Heino & Institute of Marine Research/University of Bergen & Norway \\
\hline Ernst M. Hevrøy & National Institute of Nutrition and Seafood Research & Norway \\
\hline Alf Håkon Hoel & University of Troms $\varnothing$ & Norway \\
\hline Liv Holmefjord & Directorate of Fisheries & Norway \\
\hline Grethe Hovelsrud & CICERO & Norway \\
\hline Gerd Hubold & ICES & Denmark \\
\hline Randi Ingvaldsen & Institute of Marine Research & Norway \\
\hline Fernando Jara & & Italy \\
\hline Geir Odd Johansen & Institute of Marine Research & Norway \\
\hline Reine Johansson & Baltic Sea Regional Advisory Council & Denmark \\
\hline Knut Eirik Jørstad & Institute of Marine Research & Norway \\
\hline Hrefna Karlsdóttir & Ministry of Fisheries and Agriculture & Iceland \\
\hline Brander Keith & Technical University of Denmark Aqua & Denmark \\
\hline Aslak Kristiansen & Norwegian Fishermen' Association & Norway \\
\hline Jørn Krog & Ministry of Fisheries and Coastal Affairs & Norway \\
\hline Bengt Kåmark & Swedish Board of Fisheries & Sweden \\
\hline Egil Lekven & Directorate of Fisheries & Norge \\
\hline Geir Martin Lerbukt & Ministry of Fisheries and Coastal Affairs & Norway \\
\hline Hans Linderholm & University of Gothenburg & Sweden \\
\hline Karin Linderholm & Swedish Board of Fisheries & Sweden \\
\hline Harald Loeng & Institute of Marine Research & Norway \\
\hline Torbjørn Lorentzen & Bjerknes Centre for Climate Resarch & Norway \\
\hline Cato Lyngøy & Marine Harvest Norway & Norway \\
\hline Terje Løbach & Directorate of Fisheries & Norway \\
\hline Brian MacKenzie & $\begin{array}{l}\text { National Institute for Aquatic Resources, Technical University of } \\
\text { Denmark }\end{array}$ & Denmark \\
\hline Jan Ivar Maråk & The Norwegian Fishing Vessel Owners Association & Norway \\
\hline Svein D. Mathiesen & Nordic Sámi Institute & Norway \\
\hline Ole Arve Misund & Institute of Marine Research & Norway \\
\hline Thord Monsen & Directorate of Fisheries & Norway \\
\hline Stein Mortensen & Institute of Marine Research & Norway \\
\hline Odd Nakken & Institute of Marine Research & Norway \\
\hline Tore Nepstad & Institute of marine research & Norway \\
\hline Leif Nøttestad & Institute of Marine Research & Norway \\
\hline Snorri Palmason & Directorate of Fisheries & Norway \\
\hline Helga Pedersen & Ministry of Fisheries and Coastal Affairs & Norway \\
\hline
\end{tabular}




\begin{tabular}{|c|c|c|}
\hline Name & Organization & Country \\
\hline Alexander Petrov & Atlant Pacific Norway & Norge \\
\hline Peter Prokosch & UNEP/GRID-Arendal & Norway \\
\hline Tore Riise & Ministry of Fisheries and Coastal Affairs & Norway \\
\hline Yvonne Robberstad & Institute of Marine Research & Norway \\
\hline Inger Oline Røsvik & Ministry of Fisheries and Coastal Affairs & Norway \\
\hline Ingolf Røttingen & Institute of Marine Research & Norway \\
\hline Kjersti Sandvik & Fiskaren & Norge \\
\hline Reinder Schaap & $\begin{array}{l}\text { Directorate of fisheries/Ministry of Agriculture, Nature and Food } \\
\text { Quality }\end{array}$ & $\begin{array}{l}\text { The Nether- } \\
\text { lands }\end{array}$ \\
\hline Gunnar Selvik & EFTA Secretariat & Belgium \\
\hline Øystein Skagseth & Institute of Marine Research & Norway \\
\hline Anne Skarstein & Institute of Marine Research & norway \\
\hline Anne Berit Skiftesvik & Institute of Marine Research & Norway \\
\hline Hilde Solli & Office of the Auditor General of Norway & Norway \\
\hline Doris Soto & FAO, Fisheries and Aquaculture Dep & Italy \\
\hline Christine Stangebye & Office of the Auditor General of Norway & Norge \\
\hline Jartrud Steinsli & Ministry of Fisheries and Coastal Affairs & Norway \\
\hline Anne Stene & Ministry of Fisheries and Coastal Affairs & Norway \\
\hline Ole-David Stenseth & Ministry of Fisheries and Coastal Affairs & Norway \\
\hline Jan Erik Stiansen & Institute of Marine Research & Norway \\
\hline Andreas Stokseth & $\begin{array}{l}\text { Ministry of Coastal and Fisheries Affairs/Nordic Council of Minis- } \\
\text { ters NAF/MiFi }\end{array}$ & Norway \\
\hline Anne Britt Storeng & Directorate for Nature Management & Norway \\
\hline Tore Strømme & Institute of Marine Research & Norway \\
\hline Einar Svendsen & Institute of Marine Research & Norway \\
\hline Johansen Sverre & Ministry of Fisheries and Coastal Affairs & Norway \\
\hline Kristin Thorud & Ministry of Fisheries and Coastal Affairs & Norway \\
\hline Oleg Titov & Polar Institute & Russia \\
\hline Kari Østervold Toft & Institute of marine research & Norway \\
\hline Jens Helgi Toftum & Ministry of Fisheries and natural resources & Faroe Islands \\
\hline Reidar Toresen & Institute of Marine Research & Norway \\
\hline Bill Turrell & Fisheries Research Services & Scotland \\
\hline Anne Kjos Veim & Directorate of Fisheries & Norway \\
\hline Jennifer J. West & CICERO & Norway \\
\hline Håkan Westerberg & Swedish Board of Fisheries & Sverige \\
\hline Johán H. Williams & Ministry of Fisheries and Coastal Affairs & Norway \\
\hline Inger Winsnes & Ministry of Environment & Norway \\
\hline
\end{tabular}

